\title{
A recessive gene pepy- 1 encoding Pelota confers resistance to begomovirus isolates of PepYLCIV and PepYLCAV in Capsicum annuum
}

Sota Koeda ( $\sim$ 818sota@nara.kindai.ac.jp )

Kindai University https://orcid.org/0000-0001-5921-8432

Mika Onouchi

Kindai University: Kinki Daigaku

Namiko Mori

Kindai University: Kinki Daigaku

Nadya Pohan

Kindai University: Kinki Daigaku

Atsushi J. Nagano

Keio University: Keio Gijuku Daigaku

Elly Kesumawati

Syiah Kuala University: Universitas Syiah Kuala

\section{Research Article}

Keywords: begomovirus, geminivirus, horticulture, marker-assisted breeding, pepper yellow leaf curl disease, resistance gene

Posted Date: May 26th, 2021

DOl: https://doi.org/10.21203/rs.3.rs-287025/v1

License: (9) This work is licensed under a Creative Commons Attribution 4.0 International License. Read Full License 


\section{Abstract}

Pepper yellow leaf curl disease caused by begomoviruses seriously affects pepper (Capsicum spp.) production in a number of regions around the world. Ty genes of tomato, which confer resistance to the tomato yellow leaf curl virus, are the only begomovirus resistance genes cloned to date. In this study, we focused on the identification of begomovirus resistance genes in Capsicum annuum. BaPep- 5 was identified as a novel source of resistance against pepper yellow leaf curl Indonesia virus (PepYLCIV) and pepper yellow leaf curl Aceh virus (PepYLCAV). A single recessive locus, which we named as pepper y ellow leaf curl disease virus resistance 1 (pepy-1), responsible for PepYLCAV resistance in BaPep-5 was identified on chromosome 5 in an $\mathrm{F}_{2}$ population derived from a cross between BaPep- 5 and the begomovirus susceptible accession BaPep-4. In the target region spanning $34 \mathrm{~kb}$, a single candidate gene, the messenger RNA surveillance factor Pelota, was identified. Whole-genome resequencing of BaPep-4 and BaPep-5 and comparison of their genomic DNA sequences revealed a single nucleotide polymorphism (A to $\mathrm{G}$ ) located at the splice site of the 9th intron of CaPelota in BaPep-5, which caused the insertion of the 9th intron into the transcript, resulting in the addition of 28 amino acids to CaPelota protein without causing a frameshift. Virus-induced gene silencing of CaPelota in the begomovirus susceptible pepper No.218 resulted in the gain of resistance against PepYLCIV, a phenotype consistent with BaPep-5. The DNA marker developed in this study will greatly facilitate marker-assisted breeding of begomovirus resistance in peppers.

\section{Introduction}

Five domesticated species of Capsicum have been identified to date, among which Capsicum annuum is economically the most important around the world (Pickersgill 1997; Bosland and Votava 2000). In 2019, 4.3 million tonnes of dried pepper fruits and 38 million tonnes of fresh pepper fruits were produced in the world (FAOSTAT). The largest producers of fresh peppers include China, Mexico, Turkey, Indonesia, and Spain, and together, they produce approximately $75 \%$ of the world's fresh market pepper. In Indonesia, 2.6 million tonnes of fresh market pepper fruits were produced. Chili peppers are an important source of income for vegetable farmers in Indonesia, occupying an area of at least 155,000 ha and involving more than 500,000 farmers in the country (Vos and Duriat 1995; Mustafa et al. 2006).

Pepper yellow leaf curl disease (PepYLCD) seriously affects pepper production in Indonesia (Kenyon et al. 2014b; Koeda et al. 2016). PepYLCD was first identified in West Java in 1999 (Sulandari et al. 2001, 2006; Sumardiyono et al. 2003), and an outbreak of PepYLCD was detected based on the annual crop census data from 2000 to 2006 (De Barro et al. 2008). PepYLCD is caused by viruses belonging to the Begomovirus genus of the Geminiviridae family. The genus Begomovirus encompasses 424 virus species, which carry a circular single-stranded DNA genome encapsulated in twinned icosahedral particles and rely on whitefly (Bemisia tabaci) as vectors for plant-to-plant transmission (ICTV 2019). Most begomoviruses exhibit bipartite genomes composed of two circular DNA components ( $A$ and $B$ ) of approximately 2,800 nt each (Hanley-Bowdoin et al. 2013). By contrast, monopartite begomoviruses carry only a DNA A-like genome component. 
Over the past three decades, diseases caused by begomoviruses have caused substantial yield losses in solanaceous crops, particularly tomato (Solanum lycopersicum), pepper, and eggplant (Solanum melongena), in many tropical and subtropical regions of the world (Kenyon et al., 2014b). With the increasing international importance of yellow leaf curl disease in tomato, immense efforts have been made to identify begomovirus resistance sources and to incorporate this resistance into improved tomato cultivars (Kenyon et al. 2014b). To date, six major loci (Ty-1-Ty-6) conferring resistance to the monopartite tomato yellow leaf curl virus (TYLCV) have been identified in wild tomato accessions (Zamir et al. 1994; Agrama and Scott 2006; Anbinder et al. 2009; Ji et al. 2009a, 2009b; Hutton and Scott 2014), and three of these gene (Ty-1/Ty-3/Ty-3a, Ty-2, and ty-5) have been cloned. The Ty-1, Ty-3, and Ty-3a loci are allelic and originated from Solanum chilense accessions LA1969, LA2779, and LA1932, respectively. These allelic loci encode an RNA-dependent RNA polymerase (RDR) (Zamir et al. 1994; Agrama and Scott 2006; Verlaan et al. 2013). The Ty-2 locus cloned from Solanum habrochaites accession B6013, encodes a nucleotide-binding leucine-rich repeat (NB-LRR) protein (Yamaguchi et al. 2018). The $t y-5$ gene is the only reported recessive resistance gene effective against TYLCV, which encodes the messenger RNA surveillance factor Pelota (Lapidot et al. 2015). The above-mentioned genes are the only begomovirus resistance genes identified to date, although cloning of additional resistance genes in other crops and vegetables is urgently needed.

Begomoviruses limit the cultivation of peppers in South and Southeast Asia, East and West Africa, Middle East, and North, Central and South America (Torres-Pacheco et al. 1996; Kashina et al. 2003; Khan et al. 2007; Sakata et al. 2008; Zhou et al. 2008; Zambrano et al. 2011; Martínez-Ayala et al. 2014; Ala-Poikela et al. 2015; Kumar et al. 2015; Inoue-Nagata et al. 2016; Barboza et al. 2018; Chiemsombat et al. 2018; Yasmin et al. 2018; Bornancini et al. 2020). However, breeding of resistance to begomovirus is much less advanced in pepper than in tomato, and as of yet, there are no commercial pepper cultivars carrying resistance to begomovirus infection (Kenyon et al. 2014b). However, naturally occurring begomovirus resistance has been reported in several Capsicum accessions including $C$. annuum accessions UAS12 (Retes-Manjarrez et al. 2017), S-343 (Thakur et al. 2019), DLS-Sel-10, WBC-Sel-5, PBC 142, PBC 145, PBC 345 (Srivastava et al. 2015; 2017), PBC 143, PBC 144, PBC 149, PBC 495, VI012005 (Kenyon et al. 2014a), GKC-29, BS-35, EC-497636 (Kumar et al. 2006), 9852-123 (Barchenger et al. 2019), and 'Kalyanpur Chanchal' (Singh et al. 2016), and C. chinense accessions BG-3821 (García-Neria and RiveraBustamante 2011) and 'Bhut Jolokia' (C. chinense) (Rai et al. 2014; Adluri et al. 2017). These accessions will serve as important genetic resources for breeding of begomovirus resistant commercial cultivars in the future; however, genes responsible for begomovirus resistance in these accessions have not been identified. There is still a need to continue screening the pepper germplasm for the identification of novel sources of broad, durable resistance to begomoviruses, and for cloning begomovirus resistance genes for marker-assisted breeding.

BaPep-5, a $C$. annuum accession grown locally in the Aceh province of Indonesia, was identified as a begomovirus resistant genetic resource in our preliminary analyses. Several pepper-infecting begomovirus species commonly occur in Aceh province, including bipartite begomoviruses, such as pepper yellow leaf curl Indonesia virus (PepYLCIV), pepper yellow leaf curl Aceh virus (PepYLCAV), and 
tomato yellow leaf curl Kanchanaburi virus (TYLCKaV), and a monopartite begomovirus, ageratum yellow vein virus (Koeda et al. 2016; Kesumawati et al. 2019, 2020). In the present study, we used a map-based cloning approach to identify the begomovirus resistance gene in an $F_{2}$ population derived from a cross between BaPep- 5 and the begomovirus susceptible $C$. annuum accession BaPep-4. The work presented here demonstrates that the recessive resistance of BaPep-5 against PepYLCIV and PepYLCAV results from the putative loss-of-function mutation in the messenger RNA surveillance factor Pelota.

\section{Materials And Methods}

\section{Plant material}

Two Capsicum annuum accessions, BaPep-5 (locally called Perintis) and BaPep-4 (locally called Kencana), were used in this study. $F_{1}$ and $F_{2}$ populations obtained by crossing BaPep- 5 with BaPep-4 were used for restriction site-associated DNA sequencing (RAD-seq) and fine mapping of the candidate gene. Plants were grown in a growth room with temperatures ranging from $23-30^{\circ} \mathrm{C}$ under $13-\mathrm{h} \mathrm{light/11-h}$ dark photoperiod.

\section{Begomovirus isolates}

Isolates of two bipartite begomoviruses, originally isolated in Indonesia, were used in this study: PepYLCIV isolate BA_D1-1 (Accession number of GenBank for DNA A: LC051116, DNA B: LC177332) (Koeda et al. 2016, 2018) and PepYLCAV isolate BAPep-V2 (DNA A: LC387327, DNA B: LC387329) (Kesumawati et al. 2019). PepYLCAV, originally isolated from pepper, tomato, and tobacco (Nicotiana tabacum) plants, is a recombinant begomovirus derived from PepYLCIV, the putative major parent, and pumpkin yellow mosaic virus and tomato leaf curl New Delhi virus as the minor parents (Kesumawati et al. 2019).

\section{Infectious clones}

The infectious clone of PepYLCIV isolate BA_D1-1 was previously constructed by our group through the transformation of Agrobacterium tumefaciens strain GV2260 with pGreenll-p35S-PepYLCIV-DNA-A+B (Koeda et al. 2018). To construct an infective PepYLCAV clone, full-length PepYLCAV DNA A and DNA B sequences of isolate BAPep-V2 were cloned into pGreenll-p35S, as described previously (Koeda et al. 2017). To clone PepYLCAV DNA A, two fragments were amplified by PCR: fragment 1 (full-length copy of viral DNA A) with PepYLCAV fra1 F/R primer pair, and fragment 2 (partial-length copy of viral DNA A) with PepYLCAV fra2 F/R primer pair. The linearized pGreenll-p35S plasmid (Koeda et al. 2017) was ligated with fragments 1 and 2 using the In-Fusion HD Cloning Kit (Takara Bio, Kusatsu, Shiga, Japan), and the resultant construct (pGreenll-p35S-PepYLCAV-DNA-A) was introduced into Escherichia coli (Stellar Competent Cells) (Takara Bio). To clone PepYLCAV DNA B, two fragments were amplified: fragment 1 (partial-length copy of viral DNA B) with PepYLCAV DNA-B fra1 F/R primer pair, and fragment 2 (fulllength copy of viral DNA B) with PepYLCAV DNA-B fra2 F/R primers. Ligation of linearized pGreenll-p35S and fragments 1 and 2, followed by E. colitransformation of the resultant construct (pGreenll-p35S- 
PepYLCAV-DNA-B) were conducted as described above. To clone both DNA A and DNA B of PepYLCAV into the same pGreenll-p35S vector, the DNA B partial repeat in pGreenll-p35S-PepYLCAV-DNA-B was amplified by PCR. The amplified fragment and Smal digested pGreenll-p35S-PepYLCAV-DNA-A were ligated using the In-Fusion HD Cloning Kit (Takara Bio). The resultant construct, pGreenll-p35SPepYLCAV-DNA-A+B, was transformed into E. coli. Primers used for plasmid construction are presented in Supplementary Table S1. A. tumefaciens (GV2260) was transformed with pGreenll-p35S-PepYLCAV-DNAA+B and pSoup (Hellens et al., 2000). A frozen stock of the transformed Agrobacterium was stored at $-80^{\circ} \mathrm{C}$ until needed for subsequent experiments.

\section{Inoculation of pepper plants with begomoviruses}

A single inoculation experiment was conducted for graft transmission of PepYLCIV into BaPep-5, BaPep4 , and $F_{1}$ plants. The begomovirus susceptible $C$. annuum accession No.218 was agroinfiltrated with pGreenll-p35S-PepYLCIV-DNA-A+B, as described previously (Koeda et al. 2018). The plant developmental stage is critically important for the successful infection of begomovirus by agroinfiltration.

Agroinfiltration was conducted with the optical density of 0.1 to the abaxial surface of the cotyledons which has just come out from the seed coat. The agroinfiltrated No.218 plants were used as scions, and uninoculated BaPep-5, BaPep-4, and $F_{1}$ plants were used as rootstocks. Scion plants were grafted onto rootstocks 30 days after agroinfiltration, and the grafted plants were covered by polybags to maintain high humidity. Plants were acclimatized 14 days after grafting, and most of the scion was decapitated to stimulate lateral branch growth of the rootstock. The newly developed lateral branches of BaPep-5, BaPep-4, and $F_{1}$ plants were evaluated for disease symptoms at 86 days after grafting, and young upper leaves were collected and stored at $-80^{\circ} \mathrm{C}$ until needed for DNA extraction.

Single inoculation experiments with PepYLCIV or PepYLCAV were conducted by agroinfiltration. The abaxial surface of the cotyledons of BaPep-5, BaPep-4, and $\mathrm{F}_{1}$ plants were agroinfiltrated with pGreenllp35S-PepYLCIV-DNA-A+B or pGreenII-p35S-PepYLCAV-DNA-A+B, as described previously (Koeda et al. 2017, 2018). Disease symptoms were surveyed at approximately 60 days post-inoculation (dpi), and young upper leaves were collected and stored at $-80^{\circ} \mathrm{C}$ until needed for DNA and/or RNA extraction.

The cotyledons of $F_{2}$ plants $(n=536)$ were agroinfiltrated with pGreenll-p35S-PepYLCAV-DNA-A+B, and symptoms surveys were conducted at 54 and $88 \mathrm{dpi}$. Young upper leaves were collected at 21 and $54 \mathrm{dpi}$, and stored at $-80^{\circ} \mathrm{C}$ until needed for DNA extraction.

The symptoms of each plant were scored on a disease severity index (DSI) ranging from 0 to 4 , as follows: 0 , no symptoms; 1 , very mild symptoms with slight yellowing of the leaf vein; 2 , mild yellowing of the leaf with or without the distortion of young upper leaves; 3 , moderate yellowing of the leaf with or without the distortion of leaves; 4 , heavy yellowing of the leaf with or without distortion. Statistical analysis of average DSI was performed using the Bonferroni-Dunn test of Excel Toukei ver. 7.0 at a $p$ value of 0.05 . 


\section{PepYLCIV and PepYLCAVviral DNA detection}

DNA was extracted from pepper leaves using the Nucleon PhytoPure Kit (GE Healthcare, Little Chalfont, Buckinghamshire, UK). DNA from the leaves of $\mathrm{F}_{2}$ individuals $(n=536)$ collected at $21 \mathrm{dpi}$ was extracted using a simple method, as described previously (Koeda et al. 2019a). The DNA A component of PepYLCIV was detected using Pep uni F and PI uni R primers, while PepYLCAV was detected using Pep uni F and PA uni R primers, which amplified 666- and 466-bp fragments, respectively (Kesumawati et al. 2019). PCR was performed using EmeraldAmp PCR Master Mix (Takara Bio). The amplified PCR products were subjected to electrophoresis using $1.0 \%(\mathrm{w} / \mathrm{v})$ agarose gel. Primer sequences used for viral DNA detection and PCR condition are listed in Supplementary Table S1 and Table S2.

\section{Quantification of PepYLCIV and PepYLCAV titer by real-time PCR}

The PepYLCIV and PepYLCAV DNAs were quantified using the CFX Connect Real-Time PCR Detection System (Bio-Rad, Hercules, CA, USA), as described previously (Koeda et al. 2020), with a minor modification. The DNA A components of PepYLCIV and PepYLCAV were detected by quantitative PCR (qPCR) using IV-AV Real F and R primers, which amplified 102-bp fragments. Data from the total DNA extracts were normalized relative to the $25 \mathrm{~S}$ ribosomal RNA gene (93 bp) amplified by qPCR using 25SrRNA $2 \mathrm{~F}$ and $2 \mathrm{R}$ primers. The qPCR was performed using SsoAdvanced Universal SYBR Green Supermix (Bio-Rad). Statistical analysis was performed using the Tukey-Kramer test of Excel Toukei ver.7.0 with a $p$-value of 0.05. Primer sequences used for real-time PCR and PCR condition are listed in Supplementary Table S1 and Table S2.

\section{RAD-seq and molecular mapping of the candidate gene}

DNA was extracted from pepper leaves using the Nucleon PhytoPure Kit (GE Healthcar). The RAD-seq libraries of $346 \mathrm{~F}_{2}$ individuals and their parents were constructed as described previously (Koeda et al. 2019b), and sequenced with HiSeq X Ten (Illumina, Hercules, CA, USA). Three independent replicates of parental RAD-seq libraries were constructed to minimize any bias due to PCR amplification. Raw sequence reads were preprocessed by Trimmomatic (v.0.39) (Bolger et al. 2014), where the following parameters were applied: trimmomatic PE -threads 16 -phred33 ILLUMINACLIP:TruSeq3-PE.fa:2:30:10 LEADING:19 TRAILING:19 SLIDINGWINDOW:30:20 AVGQUAL:20 MINLEN:51. The quality of trimmed reads was verified by FastQC (v.0.11.9) (Andrew 2015). The trimmed reads were mapped on to the wholegenome sequence of $C$. annuum (CM334, Pepper.v.1.6) by BWA-mem (v.0.7.17-r1188). Variant calling was conducted by GATK (v.4.1.2.0) HaplotypeCaller (Poplin et al. 2017). The obtained vcf file was filtered by VCFtools (v.0.1.16) (Danecek et al. 2011), and missing genotypes were imputed using BEAGLE (v.5.1) (Browning et al. 2018) with the default setting. The obtained RAD tags were filtered by TASSEL (v.5.2.60) (Bradbury et al. 2007), and 316 single nucleotide polymorphism (SNP) RAD tags were used to construct genetic linkage maps with MSTmap (Wu et al. 2008). Linkage analyses were conducted by composite interval mapping (CIM) of R/qtl (Broman et al. 2003).

\section{Whole-genome resequencing}


DNA was extracted from pepper leaves using the Nucleon PhytoPure Kit (GE Healthcare). Whole-genome resequencing of BaPep- 5 and BaPep- 4 was performed by the Macrogen Japan sequencing service (Macrogen Japan, Tokyo, Japan). Each sequenced sample was prepared according to the Illumina TruSeq DNA sample preparation guide to obtain a final library with an average insert size of 300-400 bp. After quality control analysis of the sample library and quantification of the DNA library templates, sequencing was conducted using NovaSeq 6000 (Illumina). Trimming and mapping of the sequence reads, followed by variant calling were performed as described above for RAD-seq. Genetic variant annotation and functional effect prediction were performed using SnpEff (v.4.3.1t) (Cingolani et al. 2012).

\section{Fine mapping}

To reduce the target region of the locus, one indel and five SNP markers were developed. To analyze indels, PCR was performed using the EmeraldAmp PCR Master Mix (Takara Bio). The amplified PCR products were subjected to electrophoresis using $8 \%$ polyacrylamide gels. To analyze SNPs, high resolution melting (HRM) analysis was conducted. Each PCR reaction contained $5 \mu \mathrm{L}$ of Precision Melt Supermix (Bio-Rad), $0.2 \mu \mathrm{M}$ of each primer, and $2.0 \mu \mathrm{L}$ of genomic DNA (30 ng/ $\mu \mathrm{L})$ in a final volume of 10 $\mu \mathrm{L}$. PCR was performed using the CFX Connect Real-Time PCR Detection System (Bio-Rad). Primer sequences used for fine mapping and PCR condition are listed in Supplementary Table S3 and Table S2.

The co-dominant cleaved amplified polymorphic sequence (CAPS) marker was used to determine the allelic state at the candidate gene in all $346 F_{2}$ individuals. PCR was performed with S05_14208507 F/R primer pair using the EmeraldAmp PCR Master Mix (Takara Bio). The PCR products were then digested with Stul restriction enzyme. Each digestion reaction (10- $\mu \mathrm{L}$ volume) contained $2 \mu \mathrm{L}$ of the PCR amplicon, $1 \mu \mathrm{L}$ of buffer (provided with the enzyme), and $0.05 \mu \mathrm{L}$ of Stul, and was incubated at $37^{\circ} \mathrm{C}$ for $2 \mathrm{~h}$. The digested products were subjected to electrophoresis using 1.0\% $(\mathrm{w} / \mathrm{v})$ agarose gel. Primer sequences used for CAPS genotyping and PCR condition are listed in Supplementary Table S3 and Table S2.

\section{Sequencing candidate gene}

Total RNA was extracted from pepper leaves using the Sepasol-RNA I Super G extraction buffer (Nacalai Tesque, Kyoto, Japan), according to the manufacturer instructions. The isolated total RNA was purified using the High-Salt Solution for Precipitation (Plant) (Takara Bio). To perform reverse-transcription PCR (RT-PCR), all RNA samples were purified and treated with DNase using the NucleoSpin RNA (Takara Bio) to remove any traces of contaminating DNA. Then, $2 \mu \mathrm{g}$ of RNA was reverse-transcribed with the oligo(dT) ${ }_{21}$ primer using the ReverTra Ace (Toyobo, Osaka, Japan) by incubation at $42{ }^{\circ} \mathrm{C}$ for $60 \mathrm{~min}$. To amplify the open reading frame (ORF) of the candidate gene, RT-PCR was performed with CaPelo full F/R primer pair using the CDNA template and KOD-plus Neo (Toyobo). The PCR products were cloned into the pTAC1 vector (BioDynamics Laboratory, Tokyo, Japan), and the resultant construct was sequenced on ABI PRISM 3100 genetic analyzer with the ABI PRISM BigDye Terminator v3.1 Cycle Sequencing Kit 
(Applied Biosystems, Foster City, CA, USA). Primer sequences used for PCR are listed in Supplementary Table S1.

\section{Phylogenetic analysis}

The MUSCLE program (Edgar 2004) was used to align the predicted amino acid sequences of Pelota belonging to different species including $C$. annuum, $C$. chinense, $C$. baccatum, $S$. lycopersicum, alfalfa (Medicago truncatula), Arabidopsis (Arabidopsis thaliana), rice (Oryza sativa), wild rice (Oryza brachyantha), sorghum (Sorghum bicolor), maize (Zea mays), Drosophila (Drosophila melanogaster), zebra fish (Danio rerio), and human (Homo sapiens). Yeast (Saccharomyces cerevisiae) Dom34 was used as an outgroup. Phylogenetic trees were constructed using the neighbor-joining method, with 1,000 bootstrap replicates, using MEGA 7.0 (Kumar et al. 2016).

\section{Expression analysis of candidate gene}

The expression of the candidate gene was analyzed by real-time quantitative reverse-transcription PCR (real-time qRT-PCR) using the CFX Connect Real-Time PCR Detection System (Bio-Rad). Each 10- $\mu \mathrm{L}$ reaction contained $5 \mu \mathrm{L}$ of SsoAdvanced Universal SYBR Green Supermix (Bio-Rad), $0.4 \mu \mathrm{M}$ of each primer, and $2.0 \mu \mathrm{L}$ of 10 -fold diluted cDNA. Transcript level of the candidate gene was normalized relative to that of CaActin (AY572427) reference gene, and relative expression of the candidate gene was calculated using the $2^{-\triangle \Delta C t}$ method. Five biological replicates, each containing three technical replicates, were analyzed. Statistical analysis was performed using Student's $t$-test with a $p$-value of 0.05. Primer sequences used for real-time qRT-PCR and PCR condition are listed in Supplementary Table S1 and Table S2.

\section{Virus-induced gene silencing (VIGS)}

VIGS was carried out using the tobacco rattle virus (TRV) vectors, pTRV1, pTRV2, pTRV2::CaPDS, and pTRV2::GFP, kindly provided by Dr. Dinesh Kumar (University of California, Davis) and Dr. Doil Choi (Seoul National University) (Chung et al. 2004).The pTRV2::CaPelota plasmid was constructed in the present study. Briefly, a partial coding sequence of CaPelota (200 bp) was amplified from BaPep-4 using KODplus Neo (Toyobo) with CaPelo fra1 F and R primers (Supplementary Table S1). The amplified product was ligated with BamHI- and Xhol-digested pTRV2 using the In-Fusion HD Cloning Kit (Takara Bio). The SGN VIGS tool was used to optimize the design of VIGS constructs to minimize similarity to off-target genes (Fernandez-Pozo et al. 2015). A. tumefaciens (GV2260) was transformed with pTRV1, pTRV2::CaPDS, pTRV2::GFP, or pTRV2::CaPelota. Frozen stocks of the transformed Agrobacterium were stored at $-80^{\circ} \mathrm{C}$ until further use.

Agrobacterium carrying pGreenIl-p35S-PepYLCIV-DNA-A+B, pTRV1, pTRV2::CaPDS, pTRV2::GFP, or pTRV2::CaPelota was grown overnight at $28{ }^{\circ} \mathrm{C}$ in $6 \mathrm{~mL}$ of LB medium containing rifampicin $(50 \mu \mathrm{g} / \mathrm{mL})$ and kanamycin $(50 \mu \mathrm{g} / \mathrm{mL})$, as described previously (Chung et al. 2004). The transformed Agrobacterium cells were harvested by centrifugation at $13,000 \times \mathrm{g}$ for $2 \mathrm{~min}$ at $20^{\circ} \mathrm{C}$ and then resuspended in $10 \mathrm{mM}$ 
MES, $10 \mathrm{mM} \mathrm{MgCl}_{2}$, and $200 \mu \mathrm{M}$ acetosyringone to the final optical density of 0.1 at $600 \mathrm{~nm}$. Cell suspensions were incubated at room temperature with shaking for $4 \mathrm{~h}$. Agrobacterium cultures containing pGreenll-p35S-PepYLCIV-DNA-A+B and pTRV1 with pTRV2::PDS, pTRV2::GFP, or pTRV2::CaPelota were mixed at a ratio of 1:1:1 for inoculation. The inoculated plants were incubated in a growth chamber maintained at $23^{\circ} \mathrm{C}$ and 12-h light/12-h dark photoperiod. Disease symptoms were surveyed at $23 \mathrm{dpi}$, and young upper leaves were collected and stored at $-80^{\circ} \mathrm{C}$ until needed for DNA and/or RNA extraction. PCR-based diagnosis of PepYLCIV and TRV was conducted using Pep uni F/PI uni R and TRV2 insert F/R primer pairs, respectively (Table S1). Statistical analysis was performed using Student's $t$-test with a $p$-value of 0.05 .

\section{Results}

\section{BaPep-5 shows resistance against PepYLCIV and PepYLCAV}

The transmission of PepYLCIV from a symptomatic No.218 scion to healthy BaPep-5, BaPep-4, or $\mathrm{F}_{1}$ rootstock was evaluated 86 days after grafting. The infection of No.218 scion by PepYLCIV was confirmed prior to grafting by PCR. The successfully grafted plants were all infected by PepYLCIV (Table 1). The PepYLCIV-infected BePep-4 $(n=13)$ and $\mathrm{F}_{1}(n=4)$ plants showed typical yellowing in the newly developed mature leaves with an average DSI of 4, whereas the PepYLCIV-infected BaPep-5 plants $(n=$ 10) showed symptom with very low severity ( $\mathrm{DSI}=1$ ) (Fig. $1 \mathrm{~A}$, Table 1$)$. Approximately $21 \%-27 \%$ of the BaPep-5, BaPep-4, and $F_{1}$ plants agroinfiltrated were infected by PepYLCIV (Table 1). These PepYLCIVinfected plants were evaluated for the disease severity. At 65 dpi, PepYLCIV-infected BaPep-4 $(n=3)$ and $\mathrm{F}_{1}(n=3)$ plants exhibited intense yellowing symptom (average DSI $\left.=4\right)$, whereas BaPep-5 plants $(n=4)$ showed symptom with very low severity $(\mathrm{DSI}=0.5)(\mathrm{Fig} .1 \mathrm{~B}$, Table 1$)$.

Approximately $66-80 \%$ of the BaPep- 5 , BaPep -4 , and $\mathrm{F}_{1}$ plants agroinfiltrated were infected by PepYLCAV and showed disease symptoms; this proportion of infected plants was higher than that infected by PepYLCIV (Table 1). These PepYLCAV-infected plants were evaluated for the disease severity. At 62 dpi, BaPep-4 $(n=33)$ and $\mathrm{F}_{1}(n=8)$ plants exhibited intense yellowing and distortion of leaves (average $=\mathrm{DSI}$ 4) (Fig. 1C, Table 1). By contrast, BaPep-5 plants showed mild symptoms, with DSI of $0(n=5), 1(n=10)$, $2(n=5)$, and $3(n=9)$ (Fig. 1D). The average DSI of BaPep-5 $(n=29)$ was 1.6, which is significantly lower than that of BaPep-4 and $\mathrm{F}_{1}$ plants (Table 1).

Plants infected with begomovirus via graft-inoculation and agroinfiltration were randomly selected for the quantification of PepYLCIV or PepYLCAV DNA by qPCR using DNA extracted from young upper leaves. At 86 days after grafting, the accumulation of PepYLCIV DNA in BaPep-5 plants $(n=10)$ was significantly lower than that in BaPep-4 $(n=13)$ and $\mathrm{F}_{1}(n=4)$ plants (Fig. 2A). Consistent results were obtained in PepYLCIV-infected BaPep-5 $(n=4)$, BaPep-4 $(n=3)$, and $\mathrm{F}_{1}(n=3)$ plants at 65 days post- agroinfiltration (Fig. 2B). Moreover, the accumulation of PepYLCAV DNA in BaPep-5 plants ( $n=19$; DSI = 0 to 3), was significantly lower at 62 dpi compared with BaPep-4 plants $(n=10 ; \mathrm{DSI}=4)$ and $\mathrm{F}_{1}$ plants $(n=8 ; \mathrm{DSI}=4)$ 
(Fig. 2C). The BaPep-5 plants with higher DSI tended to show higher PepYLCAV DNA accumulation. Together, these results suggest that unlike BaPep-4, BaPep- 5 exhibits resistance to PepYLCIV and PepYLCAV by restricting the accumulation of viral DNA. Since $F_{1}$ plants were also susceptible to both begomoviruses, the resistance of BaPep- 5 seems to be a recessive trait.

\section{Genetic mapping of the candidate gene}

The $F_{2}$ individuals $(n=536)$, derived from a cross between BaPep- 5 and BaPep-4, were agroinfiltrated with PepYLCAV BAPep-V2 isolate; PepYLCAV was chosen for agroinfiltration because of its higher infectivity (less inoculation escape) than PepYLCIV (Table 1). At 21 dpi, DNA was extracted from the young upper leaves of $F_{2}$ individuals for PCR-based diagnosis of PepYLCAV. Out of $536 F_{2}$ individuals, 346 were positive for PepYLCAV infection. The infectivity rate was approximately $65 \%$, which was consistent with the infectivity rate of BaPep-5, BaPep-4, or $\mathrm{F}_{1}$ plants $(64 \%-72 \%)$ (Table 1$)$. To avoid the use of inoculation-escaped $F_{2}$ individuals for linkage analysis, further study was conducted using only 346 PepYLCAV-positive $F_{2}$ individuals.

At $54 \mathrm{dpi}$, the $\mathrm{F}_{2}$ individuals showed the following phenotypic segregation: $n=14, \mathrm{DSI}=0 ; n=6, \mathrm{DSI}=1$; $n=2, \mathrm{DSI}=2 ; n=6, \mathrm{DSI}=3$; and $n=318, \mathrm{DSI}=4$ (Fig. 3A). At $88 \mathrm{dpi}$, the following segregation was observed: $n=24, \mathrm{DSI}=0 ; n=4, \mathrm{DSI}=1$; and $n=318, \mathrm{DSI}=4$ (Fig. 3B). Thus, the same $318 \mathrm{~F}_{2}$ individuals were constantly susceptible to PepYLCAV with DSI of 4, and symptoms recovered for the putative resistant individuals. Furthermore, we quantified PepYLCAV DNA in pepper DNA extracted from young upper leaves collected at $54 \mathrm{dpi}$ by qPCR. The relative PepYLCAV DNA level was less than 135 in resistant $28 \mathrm{~F}_{2}$ individuals and greater than 200 in susceptible 318 individuals (Fig. 3C). Additionally, the average PepYLCAV DNA accumulation was $34.3 \pm 30.7$ for BaPep-5 $(n=19), 632.9 \pm 209.1$ for BaPep-4 $(n=10)$, and $536.7 \pm 104.9$ for $\mathrm{F}_{1}(n=8)$ plants. Although the segregation ratio followed the recessive nature of the resistant, the ratio of the susceptible 318 individuals to the resistant 28 individuals did not fit 3:1 by $\chi^{2}$ test $(52.75, p=3.80 \mathrm{E}-13)$.

Next, linkage analysis of PepYLCAV resistance in BaPep- 5 was conducted using 316 SNPs obtained from RAD-seq data. The linkage map consisted of 12 linkage groups, which was equivalent to the chromosome number of pepper (C. annuum), and the average distance between DNA markers was 3.4 CM (Supplementary Fig. S1). Linkage analysis performed by CIM resulted in the detection of a single peak on chromosome 5 with the highest logarithm of the odds (LOD) score of 118 (DSI at $54 \mathrm{dpi}$ ), 172 (DSI at $88 \mathrm{dpi}$ ), and 54.4 (viral DNA accumulation at $54 \mathrm{dpi}$ ) (Fig. 4). We named this single locus as pepper yellow leaf curl disease virus resistance 1 (pepy-1), considering its recessive nature.

Initial mapping inferred that the candidate gene is located between RAD markers S05_9614395 and S05_17254971, spanning a physical distance of 4,622 kb in the reference genome sequence (CM334, Pepper.v.1.6) (Kim et al. 2014), and S05_14236545 was identified as the nearest RAD marker (Fig. 5). To reduce the size of the candidate region, one indel marker (S05_13024889) and five HRM SNP markers (S04_12817392, S05_14202764, S05_14228102, S04_14299330, and S04_14312617) were developed, 
based on the comparison of whole-genome sequences of BaPep-5 and BaPep-4. A total of 29 recombinants were identified based on genotypic and phenotypic comparisons. The susceptible phenotype of recombinant \#297 did not match the homozygous recessive (BaPep-5 allele) genotype of the S05_14202764 marker. Similarly, the resistance phenotype of recombinant \#324 did not match the heterozygous genotype of the S05_14236545 marker. The S05_14228102 marker genotype perfectly cosegregated with the phenotype in all $346 \mathrm{~F}_{2}$ individuals. These results indicated that the candidate gene was located within the genomic region of $14,203 k-14,237 k$ on chromosome 5 . Consequently, the candidate region was delimited to a 34-kb region flanked by S05_14202764 and S05_14236545 markers on either side (Fig. 5).

\section{Candidate gene analysis}

Analysis of the annotation data of the reference genome of CM334 (Pepper.v.1.6) (Kim et al. 2014) revealed that the candidate region contained a single gene, CA.PGAv.1.6.scaffold186.68 (Fig. 5). Investigation of the reference genome of Zunla (Qin et al. 2014), another $C$. annuum accession, also showed that a single gene (LOC107870304) was located within the candidate region. BLAST analysis of the putative amino acid sequence of LOC107870304 (XP_016572281) revealed that this gene was a homolog of the messenger RNA surveillance factor Pelota, which corresponds to the TYCLV resistance gene ty-5 in tomato (Lapidot et al. 2015). We named this candidate gene as CaPelota.

Phylogenetic analysis was conducted using the putative amino acid sequences of Pelota belonging to diverse species, with the yeast Dom34 as an outgroup (Fig. 6). The Drosophila, zebra fish, and human Pelota proteins constituted a single clade, while the Pelota proteins of dicot and monocot plants constituted independent clades. CaPelota showed high sequence similarity with the amino acid sequences of Pelota from C. chinense (CcPelota; PHU17047.1), C. baccatum (CbPelota; PHT54191.1), and tomato (SIPelota; (AGJ52123.1). OsPelota, which confers resistance against bacterial blight in rice (Qin et al., 2018; Zhang et al. 2018), was grouped in the clade of monocot plants.

\section{pepy-1 encodes CaPelota}

Whole-genome resequencing of BaPep-5 and BaPep-4 and comparison of their genome sequences revealed a SNP (A to $G$ in BaPep-5) at the splice site of the $9^{\text {th }}$ intron (Fig. 7A). According to the Chambon's rule, the first two and the last two nucleotides of introns are GT and AG, respectively (Rédei 2008). The nucleotide sequences of the splice site were AG in BaPep-4 and GG in BaPep-5, which was presumed to result in a splicing variant of BaPep-5. Sequencing the CaPelota ORF of BaPep-5 and BaPep4 showed that the $9^{\text {th }}$ intron was not spliced, and rather inserted into the BaPep- 5 transcript (Fig. 7A). Pelota has a tripartite structure with three domains (Lee et al. 2007). Analysis of the putative amino acid sequence of CaPelota of BaPep-5 revealed that 28 amino acids were inserted into domain 2 without causing a frameshift (Fig. 7B). The substitution of valine ${ }^{16}(\mathrm{~V})$ (susceptible M82 line) by glycine (G) (resistant TY172 line) in domain 1 is reportedly responsible for TYLCV resistance conferred by ty-5 in tomato (Lapidot et al. 2015). Similarly, the bacterial blight resistant $O$. sativa mutant $/ \mathrm{m} / 1$ carried an 
amino acid substitution in domain 1, while the genome-edited $/ \mathrm{m} / 1$ mutants (Im/1-1, Im/1-2, and $/ \mathrm{m} / 1-3$ ) and HM47 mutant carried a mutation in domain2 (Qin et al. 2018; Zhang et al. 2018). Thus, the position of the amino acid substitution in CaPelota of BaPep-5 differed from that in the Pelota of TY172, Im/1 mutants, and HM47 mutant (Fig. 7B).

Based on the A to G SNP in BaPep-5, we developed a co-dominant CAPS marker (Fig. 8A, Supplementary Fig. S2). When the PCR amplicon was digested with Stul, two fragments of 258 and 501 bp were detected in BaPep-4 (Fig. 8B), whereas a single 759-bp fragment was detected in BaPep-5, as it lacked the Stul recognition site (AGGCCT) (Fig. 8B). Genotyping all $346 \mathrm{~F}_{2}$ individuals with this CAPS marker S05_14208507 revealed that the SNP in CaPelota perfectly co-segregated with PepYLCAV resistance in the $F_{2}$ population (Table 2). The genotype of this marker explained $86.5 \%$ (DSI at $54 \mathrm{dpi}$ ), $99.1 \%$ (DSI at $88 \mathrm{dpi}$ ), and $50.6 \%$ (viral DNA accumulation at $54 \mathrm{dpi}$ ) of the phenotypic variation.

\section{Expression analysis and VIGS of CaPelota}

The expression of CaPelota in the leaves of PepYLCAV- and mock-inoculated pepper plants was analyzed by real-time qRT-PCR (Fig. 9A). The expression of CaPelota was significantly lower in mock-inoculated BaPep-5 than in mock-inoculated BaPep-4 at 46 dpi (Supplementary Fig. S3). Similar results were observed in PepYLCAV-inoculated BaPep- 5 and BaPep-4 plants at 46 and 53 dpi. The expression of CaPelota in PepYLCAV-inoculated BaPep-5 and BaPep-4 plants was higher at 53 dpi than $46 \mathrm{dpi}$.

DNA sequence analysis suggested CaPelota as a strong candidate gene responsible for PepYLCIV and PepYLCAV resistance in BaPep-5. To analyze the function of CaPelota in begomovirus resistance, we performed VIGS of CaPelota in the begomovirus susceptible accession No.218. VIGS is a powerful tool for reverse genetics in pepper, which is recalcitrant to transformation (Chung et al. 2004). The SGN VIGS tool was used to design the VIGS construct, pTRV2::CaPelota, specific for CaPelota without any off-target results.

Our preliminary investigation showed that No.218 plants co-inoculated with PepYLCAV and TRV exhibited severe disease symptoms due to the synergistic interaction of the two viruses. Therefore, PepYLCIV, which shows lower pathogenicity than PepYLCAV, was used for VIGS analysis of CaPelota. At 23 dpi, No.218 plants infected with PepYLCIV and TRV2::PDS $(n=7)$ showed photobleaching due to the silencing of the phytoene desaturase (PDS) gene (Fig. 9B). Infection by PepYLCIV and TRV was confirmed by PCR prior to further analysis. CaPelota expression, PepYLCIV DNA quantification, and DSI evaluation were conducted in No.218 plants co-infected with PepYLCIV and TRV harboring partial sequences of the green fluorescent protein (GFP) gene or CaPelota. The expression of CaPelota in the young upper leaves of plants inoculated with TRV2::CaPelota $(n=4)$ was significantly lower than that in plants inoculated with TRV2::GFP $(n=6)$ (Fig. 9C). qPCR analysis showed that the accumulation of PepYLCIV DNA in the young upper leaves was significantly lower in plants inoculated with TRV2::CaPelota compared to those infected with TRV2::GFP (Fig. 9D). Furthermore, PepYLCIV symptoms and average DSI were significantly reduced in TRV2::CaPelota-inoculated plants (Fig. 9B, E). Since the VIGS of CaPelota in No.218 plants 
resulted in the gain of resistance against PepYLCIV, we concluded that begomovirus resistance in BaPep5 is caused by the putative loss-of-function mutation in CaPelota.

\section{Discussion}

Begomoviruses, transmitted by whiteflies, have emerged as serious limitations to the cultivation of a wide variety of crops worldwide (Navas-Castillo et al., 2011; Rojas et al. 2018). This has motivated researchers and breeders to identify begomovirus resistant sources and to conduct genetic mapping of resistance loci in various crops such as tomato, pepper, melon (Cucumis melo), squash (Cucurbita moschata), common bean (Phaseolus vulgaris), cassava (Manihot esculenta), and cotton (Gossypium hirsutum) (Blair and Morales 2008; Lapidot and Levin 2017; Sáez et al. 2017, 2020; Beam and Ascencio-lbáñez 2020; Thakur et al. 2020; Zaidi et al. 2020). To the best of our knowledge, tomato Ty-1/Ty-3/ Ty-3a (encoding RDR), Ty-2 (encoding an NB-LRR protein), and ty-5 (encoding Pelota) are the only begomovirus resistance genes cloned to date (Verlaan et al. 2013; Lapdot et al. 2015; Yamaguchi et al. 2018). In the present study, we identified a begomovirus resistance gene, pepy-1 (encoding Pelota in pepper [C. annuum]), through mapbased cloning and functional characterization.

Most of the virus resistance genes in plants either prevent viral replication or restrict viral replication to the cells targeted by the virus to enter the host (Kang et al. 2005). The pepy-7-conferred resistance of BaPep -5 is a levels of virus tolerance rather than an immune response. In plants harboring the pepy- 1 gene, a low level of PepYLCIV and PepYLCAV DNA accumulation was detected in systemic leaves, but with nearly no or mild symptoms (Fig. 1, Fig. 2, Fig. 3). The TYLCV resistance genes, Ty-1/Ty-3, Ty-2, and $t y-5$, are a level of virus tolerance as well rather than immunity, consistent with our results (Verlaan et al. 2013; Lapdot et al. 2015; Yamaguchi et al. 2018).

The effectiveness of Ty gene-mediated resistance against different begomoviruses is well studied in tomato. The Ty-3a gene is fully effective against PepYLCIV but only partially effective against TYLCKaV (Koeda et al., 2020). Additionally, Ty-2-conferred resistance is effective only against some monopartite begomoviruses, such as TYLCV-IL, but not against TYLCV-Mld and other monopartite or bipartite begomoviruses (Hanson et al. 2000; Barbieri et al. 2010; Tsai et al. 2011; Shahid et al. 2013; Prasanna et al. 2015; Ohnishi et al. 2016; Yamaguchi et al. 2018). Furthermore, ty-5 is effective against TYLCV but completely ineffective against the bipartite tomato mottle virus (Gill et al. 2019). In BaPep-5, the resistance conferred by pepy- 1 was more effective against PepYLCIV than against PepYLCAV at approximately $60 \mathrm{dpi}$. PepYLCIV-infected BaPep-5 plants showed constant disease symptom with average DSI of 0.5 (Table 1). In contrast, PepYLCAV-infected BaPep-5 plants showed DSI score of 0-3 and plants with a higher disease scores tended to show higher viral accumulation (Table 1; Fig. 2C). PepYLCAV-infected pepy- 1 homozygous $\mathrm{F}_{2}$ individuals also showed the symptom range of DSI $0-3$ at 54 dpi, but symptom recovery was observed at $88 \mathrm{dpi}$ (Fig. 3). It is possible that the disease symptoms of PepYLCAV-infected BaPep-5 would have recovered until 88 dpi; however, the DSI scores of these plants were recorded only until 62 dpi (Table 1). Our preliminary data showed that PepYLCAV exhibits higher pathogenicity than PepYLCIV in the begomovirus susceptible tomato cultivar 'Momotaro' and pepper 
accession No.218 (Okabe et al. 2019). Overall, we conclude that the pepy-1 gene-conferred resistance is effective against PepYLCIV as well as PepYLCAV, and the difference between the response to PepYLCIV and PepYLCAV corresponds to the higher pathogenicity of PepYLCAV, which is a recombinant virus derived from PepYLCIV (Kesumawati et al. 2019).

The segregation ratio of phenotype in the $F_{2}$ population did not fit the expected 3:1 by $\chi^{2}$ test. In our previous study, graft-inoculation was a reliable method to avoid inoculation escapes, which are inevitably observed in agroinfiltrated pepper plants (Koeda et al. 2018). However, because the graft-inoculation method is much more laborious compared to agroinfiltration, we chose efficient agroinfiltration in the study of the $F_{2}$ population. There is a possibility that selecting 346 PepYLCAV-infected $F_{2}$ plants out of 536 inoculated plants at $21 \mathrm{dpi}$ has led to experimental bias in the segregation ratio. However, because linkage analysis conducted by CIM detected a single peak above the threshold only in chromosome 5 (Fig. 4), the genotype of SNP located at the splice site of the $9^{\text {th }}$ intron of CaPelota showed perfect cosegregation with the observed phenotype (Table 2), and the phenotypic variation explained by the developed CAPS marker was considerably high ( $99.1 \%$ for DSI at $88 \mathrm{dpi})$, we concluded that the begomovirus resistance of BaPep- 5 is controlled by a single recessive gene pepy-1. The field test in Indonesia using the same $F_{2}$ populations is ongoing, this will further clarify the segregation ratio of each genotype.

Protein translation is a strictly controlled cellular process and a part of the mechanism that eliminates aberrant transcripts and proteins (Gerovac and Tampé, 2019). Rescue of nonproductive stalled ribosomes and the associated mRNA decay is mediated by Pelota (Dom34 in yeast) and Hbs1. In the transposoninserted Drosophila mutants or knockout mutant of Pelota, the production of Pelota protein is disrupted or eliminated, and these mutants show resistance against drosophila $\mathrm{C}$ virus (DCV), a single-stranded RNA virus (Wu et al., 2014). It is presumed that the lack of Pelota protein impairs the recycling of stalled ribosomes, which reduces the availability of free ribosomes and limits the high-level synthesis of DCV capsid proteins, thus restricting the replication of DCV. Interestingly, the pelota mutant pelo/- of Drosophila also restricted the replication of cricket paralysis virus (a single-stranded RNA virus), drosophila $X$ virus (a double-stranded RNA virus), and invertebrate iridescent virus (a double-stranded DNA virus). In female mosquitoes (Aedes aegypti) co-existing with Wolbachia, a bacterial endosymbiont, the Pelota protein was downregulated, and its subcellular localization was altered, which possibly contributed to the reduction in dengue virus replication (Asad et al., 2018). Furthermore, the micro RNA (miRNA) Bta-miR-2411 induced the downregulation of the Pelota mRNA in the Madin-Darby bovine kidney cells, which restricted the replication of bovine viral diarrhea virus (Shi et al., 2018). These studies strongly suggest that PepYLCIV and PepYLCAV resistance in BaPep-5 (pepy-1) is the result of restricted replication of begomoviral DNA by Pelota deflection (Fig. 2).

Restricted viral replication caused by a mutation in Pelota seems to be the common phenomenon observed in plants and animals; however, the effect of mutation on other traits varies among organisms. The knockout mutation of Pelota is lethal in mice (Mus musculus) but not in yeast and Drosophila 
(Eberhart and Wasserman, 1995; Davis and Engrebrecht, 1998; Adham et al., 2003; Wu et al., 2014). However, the growth of the dom34 mutant strain of yeast is particularly slow at low temperature because of the reduced ribosome supply during the transition from the stationary phase, and male infertility is observed in pelota mutant of Drosophila. Although the mutation of OsPelota in rice resulted in resistance against bacterial blight and rice blast, the mutant plants showed lesion mimicking phenotype and exhibited poor performance in agronomic traits, including plant height, tiller number, panicle length, seedsetting, and 1,000-grain weight (Feng et al., 2013; Qin et al., 2018; Zhang et al., 2018). On the other hand, in a near isogenic $\mathrm{BC}_{4} \mathrm{~F}_{3}$ population of tomato developed by crossing TY172 (TYLCV resistant) and M82 (TYLCV susceptible), although begomovirus non-inoculated ty-5 homozygous plants displayed a reduction in fruit size and total fruit yield compared with $T y-5$ homozygous plants, they showed no lesion mimicking phenotype or arrested growth (Lapidot et al., 2015). BaPep-5 showed no visible growth defects or lesion mimicking phenotype in begomovirus non-infected plants (Supplementary Fig. S3). The less negative effects of Pelota mutations in pepper and tomato genetic materials enable their use for agricultural production. Because almost all pepper plants cultivated in the field are infected by begomoviruses in Indonesia (Koeda et al., 2016), even if there was a small penalty caused by the Pelota mutation, the benefit of resistance would most likely exceed the penalty cost. Evaluation of agronomic traits of BaPep- 5 and its progeny in the field under non-infected and begomovirus-infected conditions will be highly informative, and such experiments are currently being set up.

Analysis of the putative amino acid sequence of CaPelota in BaPep-5 revealed that 28 amino acids were inserted into domain 2 without causing a frameshift (Fig. 7B). Based on this finding, we conducted VIGS of CaPelota in the begomovirus susceptible pepper No.218 and revealed that silencing resulted in the gain of resistance against PepYLCIV (Fig. 9). Our result is also supported by recently reported patent that the artificial Maor ( $C$. annuum) mutant of CaPelota possessing 3 amino acids deletion in the $4^{\text {th }}$ exon showed resistant against PepYLCIV, pepper leaf curl virus, and pepper huasteco yellow vein virus (Prins et al. 2019). Interestingly, the position of mutation in CaPelota in BaPep-5 differed from previously reported mutations of Pelota genes. The amino acid substitutions caused by SNPs in TY172, Im/1, and HM47 mutants conferred resistance against begomovirus or bacterial blight (Lapidot et al. 2015; Qin et al. 2018; Zhang et al. 2018). Introducing the deletion or insertion of several nucleotides at the splice site will be relatively easy to achieve by genome editing using the CRISPR/Cas 9 system compared with introducing nonsynonymous substitutions, which needs the additional delivery of the oligonucleotide donor sequences (Bortesi and Fischer 2015). Thus, our findings provide a new opportunity for the control of begomoviruses using genome editing techniques targeted on Pelota.

As part of the Columbian Exchange, Capsicum was first introduced into Europe at the end of the fifteenth century, and its use as a horticultural crop spread rapidly throughout the Old World. Since Indonesia is not the place of origin of Capsicum, the genetic diversity for local Capsicum cultivars is presumably not as high as in Central and South America. A large outbreak of PepYLCD caused by begomoviruses in Indonesia might have increased the chance for the local farmers to select BaPep-5, which has a mutation in a plant disease susceptibility $(S)$ gene, such as Pelota. In practice, the majority of resistance breeding 
programs aim to introgress plant resistance $(R)$ genes from wild species into their cultivated relatives (Pavan et al., 2010). In most cases, resistance conferred by $R$ genes can be overcome by pathogens, resulting in widespread epidemics (Van der Hoorn et al. 2002; Panstruga and Dodds 2009). In contrast to $R$ genes, the loss-of-function mutation of $S$ genes often leads to durable and broad-spectrum resistance, such as mlo-based and elF4-based resistance (Büschges et al. 1997; Lellis et al., 2002; Piffanelli et al. 2004; Kang et al., 2005; Humphry et al. 2006 Nieto et al., 2006; Bai et al. 2008; Pavan et al. 2008). BaPep5 is a highly valuable genetic resource with recessive resistance to begomoviruses, and the DNA marker developed in this study will greatly facilitate the marker-assisted breeding of begomovirus resistance in peppers.

\section{Declarations}

\section{Acknowledgments}

This study was supported by the Japan Society for the Promotion of Science (JSPS) KAKENHI Grant Number $19 \mathrm{H} 02950$ to S. Koeda, and JSPS-DG-RSTHE Joint Research Program for S. Koeda and E. Kesumawati. We thank Satoko Kondo (Ryukoku University) for supporting RAD-seq library preparation. We thank Fitrizal, Munawar Khalil, Gian Alfan, Putra Bahagia, and Dharma Setiawan (Syiah Kuala University) for supporting our preliminary survey of BaPep-5 at Aceh, Indonesia.

\section{Funding}

This study was supported by the Japan Society for the Promotion of Science (JSPS) KAKENHI Grant Number $19 \mathrm{H} 02950$ to S. Koeda, and JSPS-DG-RSTHE Joint Research Program for S. Koeda and E. Kesumawati.

\section{Conflict of interest/Competing interests}

The authors declare no conflict/competing of interest.

\section{Availability of data and material}

Accession numbers for each of the gene sequences referred to in this work are as follows: mRNA sequences of BaPep-5 (LC594629) and BaPep-4 (LC594630).

\section{Code availability}

Not applicable

\section{Authors' contributions}

SK designed the experiments; performed genetic mapping; analyzed the data; interpreted the results and wrote the manuscript. MO performed virus inoculation, resistance evaluation, genetic mapping, gene 
expression analysis, and VIGS. NM performed virus inoculation, resistance evaluation. NP and EK prepared the material. AJN, performed RAD-seq. All authors read and approved the final manuscript.

\section{References}

Adham IM, Sallam MA, Steding G, Korabiowska M, Brinck U, Hoyer-Fender S, Oh C, Engel W (2003) Disruption of the pelota gene causes early embryonic lethality and defects in cell cycle progression. Mol Cell Biol 23:1470-1476

Adluri PK, Baldoldiya GM, Nath PD (2017) Screening of Bhut Jolokia (Capsicum chinense Jacq.) germplasm of North East India against chili leaf curl virus. Int J Pure Appl Biosci 5:1189-1196

Agrama HA, Scott JW (2006) Quantitative trait loci for Tomato yellow leaf curl virus and Tomato mottle virus resistance in tomato. J Am Soc Hortic Sci 131:267-272

Ala-Poikela M, Svensson E, Rojas A, Horko T, Paulin L, Valkonen J, Kvarnheden A (2005) Genetic diversity and mixed infections of begomoviruses infecting tomato, pepper and cucurbit crops in Nicaragua. Plant Pathol 54:448-459

Anbinder I, Reuveni M, Azari R, Paran I, Nahon S, Shlomo H, Chen L, Lapidot M, Levin I (2009) Molecular dissection of Tomato leaf curl virus resistance in tomato line TY172 derived from Solanum peruvianum. Theor Appl Genet 119:519-530

Andrews S (2015) FastQC a quality control tool for high throughput sequence data. Babranam Institute Asad S, Hussain M, Hugo L, Osei-Amo S, Zhang G, Watterson D, Asgari S (2018) Suppression of the pelo protein by Wolbachia and its effect on dengue virus in Aedes aegypti. PLoS Negl Trop Dis 12:e0006405

Bai Y, Pavan S, Zheng Z, Zappel NF, Reinstadler A, Lotti C, De Giovanni C, Ricciardi L, Lindhout P, Visser R, Theres K, Panstruga R (2008) Naturally occurring broad-spectrum powdery mildew resistance in a Central American tomato accession is caused by loss of mlo function. Mol Plant Microbe Interact 21:30-39

Barbieri M, Acciarri N, Sabatini E, Sardo L, Accotto GP, Pecchioni N (2010) Introgression of resistance to two Mediterranean virus species causing tomato yellow leaf curl into a valuable traditional tomato variety. J Plant Pathol 92:485-493

Barboza N, Blanco-Meneses M, Esker P, Moriones E, Inoue-Nagata AK (2018) Distribution and diversity of begomoviruses in tomato and sweet pepper plants in Costa Rica. Ann Appl Biol 172:20-32

Barchenger DW, Yule S, Jeeatid N, Lin S, Wang Y, Lin T, Chan Y, Kenyon L (2019) A novel source of resistance to Pepper yellow leaf curl Thailand virus (PepYLCThV) (Begomovirus) in chile pepper. HortScience 54:2146-2149

Beam K, Ascencio-Ibáñez JT (2020) Geminivirus Resistance: A Minireview. Front Plant Sci 11:1131 
Blair MW, Morales FJ (2008) Geminivirus Resistance Breeding in Common Bean, in CAB Reviews: Perspectives in Agriculture, Veterinary Science, Nutrition and Natural Resources, (CABI Wallingford UK) vol. 3. doi: 10.1079/PAVSNNR20083089

Bolger AM, Lohse M, Usadel B (2014) Trimmomatic: a flexible trimmer for Illumina sequence data. Bioinformatics 30: 2114-2120

Bornancini VA, Irazoqui JM, Flores CR, Vaghi Medina CG, Amadio AF, López Lambertini PM (2020) Reconstruction and characterization of full-length begomovirus and alphasatellite genomes infecting pepper through metagenomics. Viruses 12:202

Bortesi L, Fischer R (2015) The CRISPR/Cas9 system for plant genome editing and beyond. Biotechnol Adv 33:41-52

Bosland PW, Votava EJ (2000) Peppers: vegetable and spice capsicums. CABI Publishing, New York.

Bradbury PJ, Zhang Z, Kroon DE, Casstevens TM, Ramdoss Y, Buckler ES (2007) TASSEL: software for association mapping of complex traits in diverse samples. Bioinformatics 23:2633-2635

Broman KW, Wu H, Sen Ś, Churchill GA (2003) R/qtl: QTL mapping in experimental crosses. Bioinformatics 19:889-890

Browning BL, Zhou Y, Browning SR (2018) A one-penny imputed genome from next generation reference panels. Am J Hum Genet 103:338-348

Büschges R, Hollricher K, Panstruga R, Simons G, Wolter M, Frijters A, van Daelen R, van der Lee T, Diergaarde P, Groenendijk J, Topsch S, Vos P, Salamini F, Schulze-Lefert P (1997) The barley Mlo gene: a novel control element of plant pathogen resistance. Cell 88:695-705

Chiemsombat P, Srikamphung B, Yule S (2018) Begomoviruses associated to pepper yellow leaf curl disease in Thailand. J Agric Res 37000183doi, 10.23880/oajar-16000183

Chung E, Seong E, Kim YC, Chung EJ, Oh SK, Lee S, Park JM, Joung YH, Choi D (2004) A method of high frequency virus-induced gene silencing in chili pepper (Capsicum annuum L. cv. Bukang). Mol Cells $17: 377-380$

Cingolani P, Platts A, Wang le L, Coon M, Nguyen T, Wang L, Land SJ, Lu X, Ruden DM (2012) A program for annotating and predicting the effects of single nucleotide polymorphisms, SnpEff: SNPs in the genome of Drosophila melanogaster strain w1118; iso-2; iso-3. Fly (Austin) 6:80-92

Danecek P, Auton A, Abecasis G, Albers CA, Banks E, DePristo MA, Handsaker RE, Lunter G, Marth GT, Sherry ST, McVean G, Durbin R (2011) The variant call format and VCFtools. Bioinformatics 27:21562158 
Davis L, Engebrecht J (1998) Yeast dom34 mutants are defective in multiple developmental pathways and exhibit decreased levels of polyribosomes. Genetics 149:45-56

De Barro PJ, Hidayat SH, Frohlich D, Subandiyah S, Ueda S (2008) A virus and its vector, pepper yellow leaf curl virus and Bemisia tabaci, two new invaders of Indonesia. Biol Invasions 10:411-433

Eberhart CG, Wasserman SA (1995) The pelota locus encodes a protein required for meiotic cell division: an analysis of G2/M arrest in Drosophila spermatogenesis. Development 121:3477-3486

Edgar RC (2004) MUSCLE: multiple sequence alignment with high accuracy and high throughput. Nucleic Acids Res 32:1792-1797

Feng BH, Yang Y, Shi YF, Shen HC, Wang HM, Huang QN, Xu X, Lu XG, Wu JL (2013) Characterization and genetic analysis of a novel rice spotted-leaf mutant HM47 with broad-spectrum resistance to Xanthomonas oryzae pv. oryzae. J Integr Plant Biol 55:473-483

Fernandez-Pozo N, Rosli HG, Martin GB, Mueller LA (2015) The SGN VIGS tool: user-friendly software to design virus-induced gene silencing (VIGS) constructs for functional genomics. Mol Plant 8:486-488

García-Neria MA, Rivera-Bustamante RF (2011) Characterization of geminivirus resistance in an accession of Capsicum chinense Jacq. Mol Plant Microbe Interact 24:172-182

Gerovac M, Tampé R (2019) Control of mRNA translation by versatile ATP-driven machines. Trends Biochem Sci 44:167-180

Gill U, Scott JW, Shekasteband R, Ogundiwin E, Schuit C, Francis DM, Sim SC, Smith H, Hutton SF (2019) Ty-6, a major begomovirus resistance gene on chromosome 10, is effective against Tomato yellow leaf curl virus and Tomato mottle virus. Theor Appl Genet 132:1543-1554

Hanson PM, Bernacchi D, Green S, Tanksley SD, Muniyappa V, Padmaja S, Chen HM, Kuo G, Fang D, Chen JT (2000) Mapping a wild tomato introgression associated with tomato yellow leaf curl virus resistance in a cultivated tomato line. J Am Soc Hortic Sci 125:15-20

Hanley-Bowdoin L, Bejarano ER, Robertson D, Mansoor S (2013) Geminiviruses: masters at redirecting and reprogramming plant processes. Nat Rev Microbiol 11:777-788

Hellens RP, Edwards EA, Leyland NR, Bean S, Mullineaux PM (2000) pGreen: a versatile and flexible binary Ti vector for Agrobacterium-mediated plant transformation. Plant Mol Biol 42:819-832

Humphry M, Consonni C, Panstruga R (2006) mlo-based powdery mildew immunity: silver bullet or simply nonhost resistance? Mol Plant Pathol 7:605-610

Hutton SF, Scott JW (2014) Ty-6, a major begomovirus resistance gene located on chromosome 10. Rep Tomato Genet Coop 64:14-18 
International committee on taxonomy of viruses (2019) https://talk.ictvonline.org/taxonomy/ Accessed on 8th Apr 2021

Inoue-Nagata AK, Lima MF, Gilbertson RL (2016) A review of geminivirus diseases in vegetables and other crops in Brazil: current status and approaches for management. Hortic Bras 34:8-18

Ji Y, Scott JW, Schuster DJ (2009a) Toward fine mapping of the Tomato yellow leaf curl virus resistance gene $T y$-2 on chromosome 11 of tomato. Hortscience 44:614-618

Ji Y, Scott JW, Schuster DJ, Maxwell DP (2009b) Molecular mapping of $T y-4$, a new tomato yellow leaf curl virus resistance locus on chromosome 3 of tomato. J Am Soc Hortic Sci 134:281-288

Kang BC, Yeam I, Jahn MM (2005) Genetics of plant virus resistance. Annu Rev Phytopathol 43:581-621

Kang BC, Yeam I, Frantz JD, Murphy JF, Jahn MM (2005) The pvr1 locus in Capsicum encodes a translation initiation factor elF4E that interacts with Tobacco etch virus VPg. Plant J 42:392-405

Kashina BD, Mabagala RB, Mpunami AA (2003) Biomolecular relationships among isolates of Tomato Yellow Leaf Curl Tanzania Virus. Phytoparasitica 31:188-199

Kenyon L, Kumar S, Tsai WS, Hughes Jd'A (2014a) Virus diseases of peppers (Capsicum spp.) and their control. In: G. Loebenstein and N. Katis (eds.). Advances in virus research. Vol. 90. Academic Press p. 297-254

Kenyon L, Tsai WS, Shih SL, Lee LM (2014b) Emergence and diversity of begomoviruses infecting solanaceous crops in East and Southeast Asia. Virus Res 186:104-113

Kesumawati E, Okabe S, Homma K, Fujiwara I, Zakaria S, Kanzaki S, Koeda S (2019) Pepper yellow leaf curl Aceh virus: A novel bipartite begomovirus isolated from chili pepper, tomato, and tobacco plants in Indonesia. Arch Virol 164:2379-2383

Kesumawati E, Okabe S, Khalil M, Alfan G, Bahagia P, Pohan N, Zakaria S, Koeda S (2020) Molecular characterization of begomoviruses associated with yellow leaf curl disease in Solanaceae and Cucurbitaceae crops from Northern Sumatra, Indonesia. Hort J 89:410-416

Khan JA, Al-Saady NA, Al-Mahruki MS, Al-Oufi M, Al-Subhi AM (2007) Molecular characterization of begomovirus infecting sweet pepper in Oman. Indian J Biotechnol 6:45-51

Kim S, Park M, Yeom SI et al (2014) Genome sequence of the hot pepper provides insights into the evolution of pungency in Capsicum species. Nat Genet 46:270-278

Koeda S, Fujiwara I (2019a) A simple DNA extraction method for begomovirus detection and genotyping of host plants. Trop Agric Dev 63:34-37 
Koeda S, Fujiwara I, Oka Y, Kesumawati E, Zakaria S, Kanzaki S (2020) Ty-2 and Ty-3a conferred resistance are insufficient against Tomato yellow leaf curl Kanchanaburi virus from Southeast Asia in single or mixed infections of tomato. Plant Dis 104:3221-3229

Koeda S, Homma K, Tanaka Y, Kesumawati E, Zakaria S, Kanzaki S (2017) Highly efficient agroinoculation method for tomato plants with Tomato yellow leaf curl Kanchanaburi virus. Hort J $86: 479-486$

Koeda S, Homma K, Tanaka Y, Onizaki D, Kesumawati E, Zakaria S, Kanzaki S (2018) Inoculation of capsicums with Pepper yellow leaf curl Indonesia virus by combining agroinoculation and grafting. Hort $\mathrm{J}$ 87:364-371

Koeda S, Kesumawati E, Tanaka Y, Hosokawa M, Doi M, Kitajima A (2016) Mixed infection of begomoviruses on pepper plants at Northern Sumatra, Indonesia. Trop Agric Dev 60:59-64

Koeda S, Sato K, Saito H, Nagano AJ, Yasugi M, Kudoh H, Tanaka Y (2019b) Mutation in the putative ketoacyl-ACP reductase CaKR1 induces loss of pungency in Capsicum. Theor Appl Genet 132:65-80

Kumar S, Kumar S, Singh M, Singh AK, Rai M (2006) Identification of host plant resistance to pepper leaf curl virus in chilli (Capsicum species). Sci Hort 110:359-361

Kumar RV, Singh AK, Singh AK, Yadav T, Basu S, Kushwaha N, Chattopadhyay B, Chakraborty S (2015) Complexity of begomovirus and betasatellite population associated with chilli leaf curl disease in India. $J$ Gen Virol 96:3143-3158

Kumar S, Stecher G, Tamura K (2016) MEGA7: molecular evolutionary genetics analysis version 7.0 for bigger datasets. Mol Biol Evol 33:1870-1874

Lapidot M, Karniel U, Gelbart D, Fogel D, Evenor D, Kutsher Y, Makhbash Z, Nahon S, Shlomo H, Chen L, Reuveni M, Levin I (2015) A novel route controlling begomovirus resistance by the messenger RNA surveillance factor Pelota. PLoS Genet 11:e1005538

Lapidot M, Levin I (2017) Genetic resistance to viruses in tomato. Achieving Sustainable Cultivation of Tomatoes (Autar Mattoo and Avtar Handa, Burleigh Dodds Science Publishing 381-400

Lee HH, Kim YS, Kim KH et al (2007) Structural and functional insights into Dom34, a key component of no-go mRNA decay. Mol Cell 27:938-950

Lellis AD, Kasschau KD, Whitham SA, Carrington JC (2002) Loss-of-susceptibility mutants of Arabidopsis thaliana reveal an essential role for elF(iso)4E during potyvirus infection. Curr Biol 12:1046-1051

Martínez-Ayala A, Sanchez-Campos S, Caceres F, Aragon-Caballero L, Navas-Castillo J, Moriones E (2014) Characterisation and genetic diversity of pepper leafroll virus, a new bipartite begomovirus infecting pepper, bean and tomato in Peru. Ann Appl Biol 164:62-72 
Mustafa U, Ali M, Kuswanti H (2006) Indonesia. In: Ali M (ed) Chilli (Capsicum spp.) food chain analysis: setting research priorities in Asia. AVRDC-The World Vegetable Center, Shanhua. Technical Bulletin No. 38, AVRDC Publication 06-678, 253

Navas-Castillo J, Fiallo-Olivé E, Sánchez-Campos S (2011) Emerging virus diseases transmitted by whiteflies. Annu Rev Phytopathol 49:219-248

Nieto C, Morales M, Orjeda G, Clepet C, Monfort A, Sturbois B, Puigdomenech P, Pitrat M, Caboche M, Dogimont C, Garcia-Mas J, Aranda MA, Bendahmane A (2006) An elF4E allele confers resistance to an uncapped and non-polyadenylated RNA virus in melon. Plant J 48:452-462

Ohnishi J, Yamaguchi H, Saito A (2016) Analysis of the Mild strain of tomato yellow leaf curl virus, which overcomes Ty-2 gene-mediated resistance in tomato line H24. Arch Virol 161:2207-2217

Okabe S, Kesumawati E, Zakaria S, Kanzaki S, Koeda S (2019) Growth inhibition of pepper and tomato plants caused by a new begomovirus PepYLCAV. Hort. Res. (Japan) 18:181 (in Japanese)

Panstruga R, Dodds PN (2009) Terrific protein traffic: the mystery of effector protein delivery by filamentous plant pathogens. Science 324:748-750

Pavan S, Jacobsen E, Visser RG, Bai Y (2010) Loss of susceptibility as a novel breeding strategy for durable and broad-spectrum resistance. Mol Breed. 25:1-12

Pavan S, Zheng Z, van den Berg P, Lotti C, De Giovanni C, Borisova M, Lindhout P, de Jong H, Ricciardi L, Visser R, Bai Y (2008) Map- vs homology-based cloning for the recessive gene ol-2 conferring resistance to tomato powdery mildew. Euphytica 162:91-98

Pickersgill B (1997) Genetic resources and breeding of Capsicum spp. Euphytica 96:129-133

Piffanelli P, Ramsay L, Waugh R, Benabdelmouna A, D'Hont A, Hollricher K, Jorgensen JH, Schulze-Lefert $\mathrm{P}$, Panstruga R (2004) A barley cultivation-associated polymorphism conveys resistance to powdery mildew. Nature 430:887-891

Poplin R, Ruano-Rubio V, DePristo MA, Tim J, Fennell, Mauricio O, Carneiro V, Auwera, Geraldine A, David E. Kling LD, Gauthier A, Levy-Moonshine D, Roazen et al (2017) Scaling accurate genetic variant discovery to tens of thousands of samples. http://biorxiv.org/content/early/2017/11/14/201178.1.abstract.

Prasanna HC, Sinha DP, Rai GK, Krishna R, Kashyap SP, Singh NK, Singh M, Malathi VG (2015) Pyramiding $T y-2$ and $T y-3$ genes for resistance to monopartite and bipartite tomato leaf curl viruses of India. Plant Pathol 64:256-264

Prins MW, Van Enckevort LJG, Versluis HP (2019) Geminivirus resistant plants. WO2019122374. 
Qin P, Fan S, Deng L, Zhong G, Zhang S, Li M, Chen W, Wang G, Tu B, Wang Y, Chen X, Ma B, Li S (2018) LML1, encoding a conserved Eukaryotic release factor 1 protein, regulates cell death and pathogen resistance by forming a conserved complex with SPL33 in Rice. Plant Cell Physiol 59:887-902

Qin C, Yu CS, Shen YO et al (2014) Whole-genome sequencing of cultivated and wild peppers provides insights into Capsicum domestication and specialization. Proc Natl Acad Sci USA 111:5135-5140

Rai VP, Kumar R, Singh SP, Kumar S, Kumar S, Singh M, Rai M (2014) Monogenic recessive resistance to Pepper leaf curl virus in an interspecific cross of Capsicum. Sci Hort 172:34-38

Rédei GP (2008) Encyclopedia of Genetics, Genomics, Proteomics, and Informatics. GT - AG RULE (Chambon's rule). Springer, Houten

Retes-Manjarrez J, Hernández-Verdugo S, López-Orona C, Medina-López R, Garzón-Tiznado J, RetesCázarez J (2019) Inheritance of resistance to Pepper huasteco yellow vein virus in Capsicum annuum L., HortScience 54:783-786

Rojas MR, Macedo MA, Maliano MR et al (2018) World management of Geminiviruses. Annu Rev Phytopathol 56:637-677

Sáez C, Esteras C, Martínez C, Ferriol M, Dhillon NPS, López C, Picó B (2017) Resistance to tomato leaf curl New Delhi virus in melon is controlled by a major QTL located in chromosome 11. Plant Cell Rep $36: 1571-1584$

Sáez C, Martínez C, Montero-Pau J, Esteras C, Sifres A, Blanca J, Ferriol M, López C, Picó B (2020) A major QTL located in chromosome 8 of Cucurbita moschata is responsible for resistance to Tomato leaf curl New Delhi virus. Front Plant Sci 11:207

Sakata JJ, Shibuya Y, Sharma P, Ikegami M (2008) Strains of a new bipartite begomovirus, pepper yellow leaf curl Indonesia virus, in leaf-curl-diseased tomato and yellow-vein-diseased ageratum in Indonesia. Arch Virol 153:2307-2313

Shahid MS, Ito T, Kimbara J, Onozato A, Natsuaki KT, Ikegami M (2013) Evaluation of tomato hybrids carrying Ty-1 and Ty-2 loci to Japanese monopartite begomovirus species. J Phytopathol 161:205-209

Shi H, Fu Q, Li S, Hu X, Tian R, Yao G, Zhao H, Wang J (2018) Bta-miR-2411 attenuates bovine viral diarrhea virus replication via directly suppressing Pelota protein in Madin-Darby bovine kidney cells. Vet Microbiol 215:43-48

Singh AK, Kushwaha N, Chakraborty S (2016) Synergistic interaction among begomoviruses leads to suppression of host defense-related gene expression and breakdown of resistance in chilli. Appl Microbiol Biotechnol 100:4035-4049 
Srivastava A, Mangal M, Saritha RK, Jat SL, Gosavy GU, Kalia P (2015) Natural epiphytotic screening of chilli germplasm lines against leaf curl virus complex. Int J Trop Agric 33:3581-3586

Srivastava A, Mangal M, Saritha RK, Kalia P (2017) Screening of chilli pepper (Capscium spp.) lines for resistance to the begomovirus causing chili leaf curl disease in India. Crop Prot 100:177-185

Sulandari S, Suseno R, Hidayat SH, Harjosudarmo J, Sosromarsono S (2001) Deteksi virus Gemini pada cabai di daerah istimewa Yogyakarta. Prodising Kongres Nasional XVI dan Seminar Ilmiah. PFI, Bogor, pp 200-202

Sulandari S, Suseno R, Hidayat SH, Harjosudarmo J, Sosromarsono S (2006) Detection and host range study of virus associated with pepper yellow leaf curl disease. Hayati 13:1-6

Sumardiyono YB, Sulandari S, Hartono S (2003) Epidemi Penyakit Daun Keriting Kuning Cabai. J Perlindungan Tanaman Indonesia. 9:1-3

Thakur H, Jindal SK, Sharma A, Dhaliwal MS (2019) A monogenic dominant resistance for leaf curl virus disease in chilli pepper (Capsicum annuum L.). Crop Prot 116:115-120

Thakur H, Jindal SK, Sharma A, Dhaliwal MS (2020) Molecular mapping of dominant gene responsible for leaf curl virus resistance in chilli pepper (Capsicum annuum L.). 3 Biotech 10:182

Torres-Pacheco I, Garzon-Tiznado JA, Brown JK, Becerra-Flora A, Rivera-Bustamante R (1996) Detection and distribution of geminiviruses in Mexico and the southern United States. Phytopathology 86:11861192

Tsai WS, Shih SL, Kenyon L, Green SK, Jan FJ (2011) Temporal distribution and pathogenicity of the predominant tomato-infecting begomoviruses in Taiwan. Plant Pathol 60:787-799

Van der Hoorn RAL, De Wit PJ, Joosten MH (2002) Balancing selection favors guarding resistance proteins. Trends Plant Sci 7:67-71

Verlaan MG, Hutton SF, Ibrahem RM, Kormelink R, Visser RGF, Scott JW, Edwards JD, Bai Y (2013) The Tomato yellow leaf curl virus resistance genes $T y-1$ and $T y-3$ are allelic and code for DFDGD-class RNAdependent RNA polymerases. PLoS Genet 9:e1003399

Vos JGM, Duriat AS (1995) Hot pepper (Capsicum Spp.) production on Java, Indonesia-toward integrated crop management. Crop Prot 14:205-213

Wu Y, Bhat PR, Close TJ, Lonardi S (2008) Efficient and accurate construction of genetic linkage maps from the minimum spanning tree of a graph. PLoS Genet 4: e1000212

Wu X, He WT, Tian S, Meng D, Li Y, Chen W, Li L, Tian L, Zhong CQ, Han F, Chen J, Han J (2014) pelo is required for high efficiency viral replication. PLoS Pathog 10:e1004034 
Yamaguchi H, Ohnishi J, Saito A, Ohyama A, Nunome T, Miyatake K, Fukuoka H (2018) An NB-LRR gene, TYNBS1, is responsible for resistance mediated by the Ty-2Begomovirus resistance locus of tomato.

Theor Appl Genet 131:1345-1362

Yasmin S, Raja NI, Hameed S, Abbas Z (2018) Detection and molecular characterization of begomoviruses infecting chilli pepper. Int J Biosci 13:267-271

Zaidi SS, Naqvi RZ, Asif M, Strickler S, Shakir S, Shafiq M, Khan AM, Amin I, Mishra B, Mukhtar MS, Scheffler BE, Scheffler JA, Mueller LA, Mansoor S (2020) Molecular insight into cotton leaf curl geminivirus disease resistance in cultivated cotton (Gossypium hirsutum). Plant Biotechnol J 18:691706

Zambrano K, Geraud-Pouey F, Chirinos D, Romay G, Marys E (2011) Tomato chlorotic leaf distortion virus, a new bipartite begomovirus infecting Solanum lycopersicum and Capsicum chinense in Venezuela. Arch Virol 156:2263-2266

Zamir D, Eksteinmichelson I, Zakay Y, Navot N, Zeidan M, Sarfatti M, Eshed Y, Harel E, Pleban T, Vanoss H, Kedar N, Rabinowitch HD, Czosnek H (1994) Mapping and introgression of a tomato yellow leaf curl virus tolerance Gene, Ty-1. Theor Appl Genet 88:141-146

Zhang XB, Feng BH, Wang HM, Xu X, Shi YF, He Y, Chen Z, Sathe AP, Shi L, Wu JL (2018) A substitution mutation in OSPELOTA confers bacterial blight resistance by activating the salicylic acid pathway. $\mathrm{J}$ Integr Plant Biol 60:160-172

Zhou YC, Noussourou M, Kon T, Rojas M, Jiang H, Chen L, Gamby K, Foster R, Gilbertson R (2008) Evidence of local evolution of tomato-infecting begomovirus species in West Africa: characterization of tomato leaf curl Mali virus and tomato yellow leaf crumple virus from Mali. Arch Virol 153:693-706

\section{Figures}



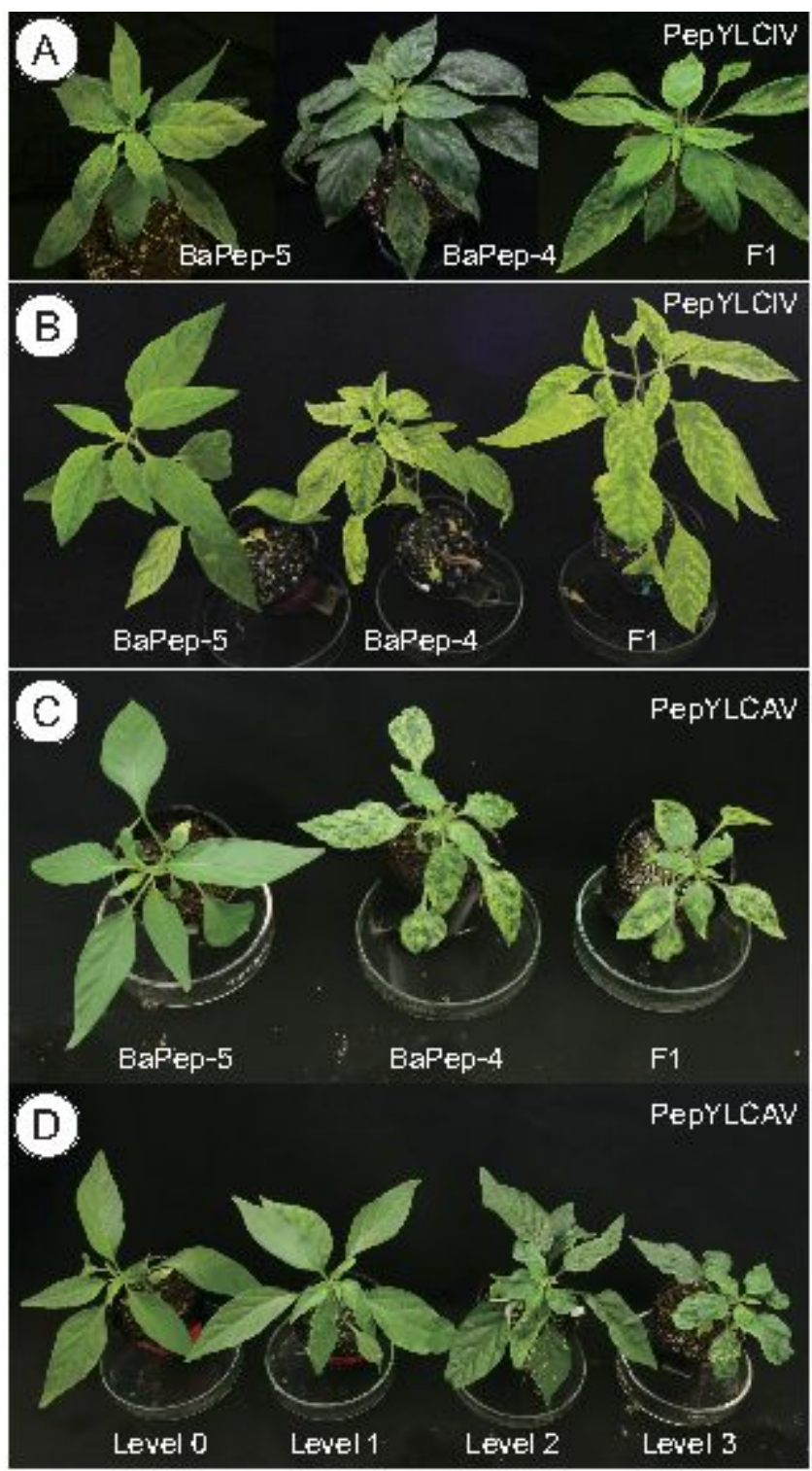

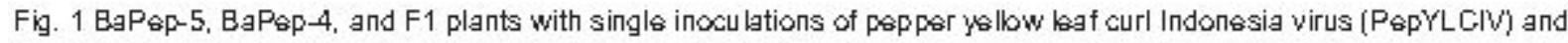

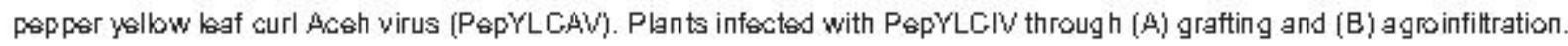

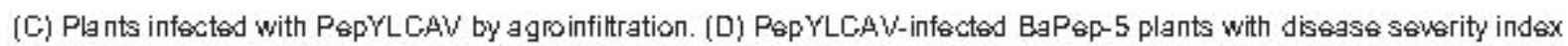
(DSI) ranging from 0 to 3 . Pictures wars taksn at (A) 86 days post-grafting. (B) 65 days post-inoculation (dpi), and (C and D) 62 dpi.

\section{Figure 1}

BaPep-5, BaPep-4, and F1 plants with single inoculations of pepper yellow leaf curl Indonesia virus (PepYLCIV) and pepper yellow leaf curl Aceh virus (PepYLCAV). Plants infected with PepYLCIV through (A) grafting and (B) agroinfiltration. (C) Plants infected with PepYLCAV by agroinfiltration. (D) PepYLCAVinfected BaPep-5 plants with disease severity index (DSI) ranging from 0 to 3 . Pictures were taken at (A) 86 days post-grafting, (B) 65 days post-inoculation (dpi), and (C and D) $62 \mathrm{dpi}$. 
(A)

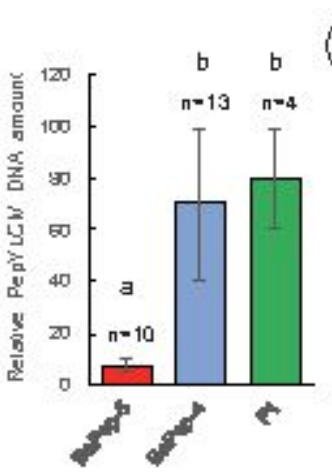

(B)

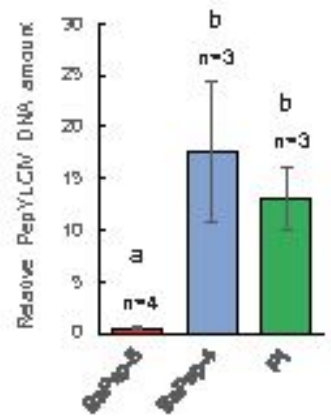

(C)

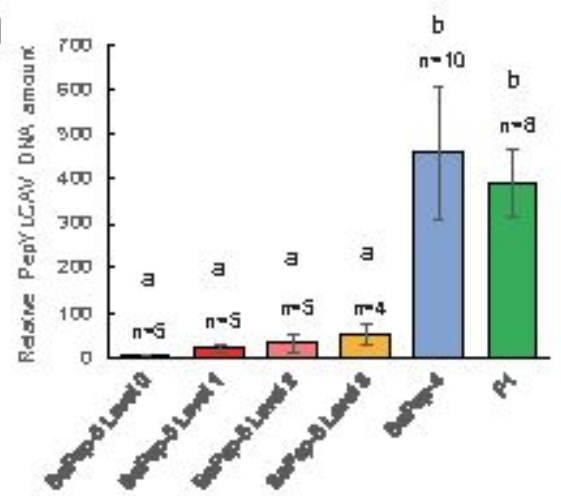

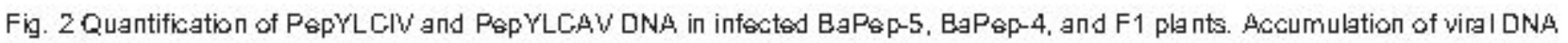
(A) in PapYLCNV-infœct@ plants at as days post-grafting and (B) at 65 dpi and (C) in P仓pYLCAV-infœct@d plants at 62 dpi. Viral DNA

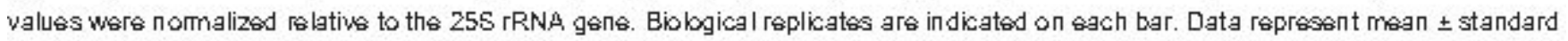

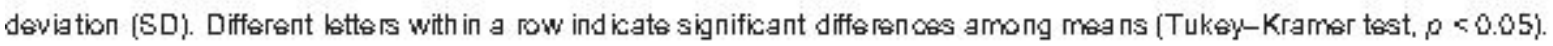

\section{Figure 2}

Quantification of PepYLCIV and PepYLCAV DNA in infected BaPep-5, BaPep-4, and F1 plants. Accumulation of viral DNA (A) in PepYLCIV-infected plants at 86 days post-grafting and (B) at 65 dpi and (C) in PepYLCAV-infected plants at 62 dpi. Viral DNA values were normalized relative to the 25S rRNA gene. Biological replicates are indicated on each bar. Data represent mean \pm standard deviation (SD). Different letters within a row indicate significant differences among means (Tukey-Kramer test, $p<0.05$ ). 

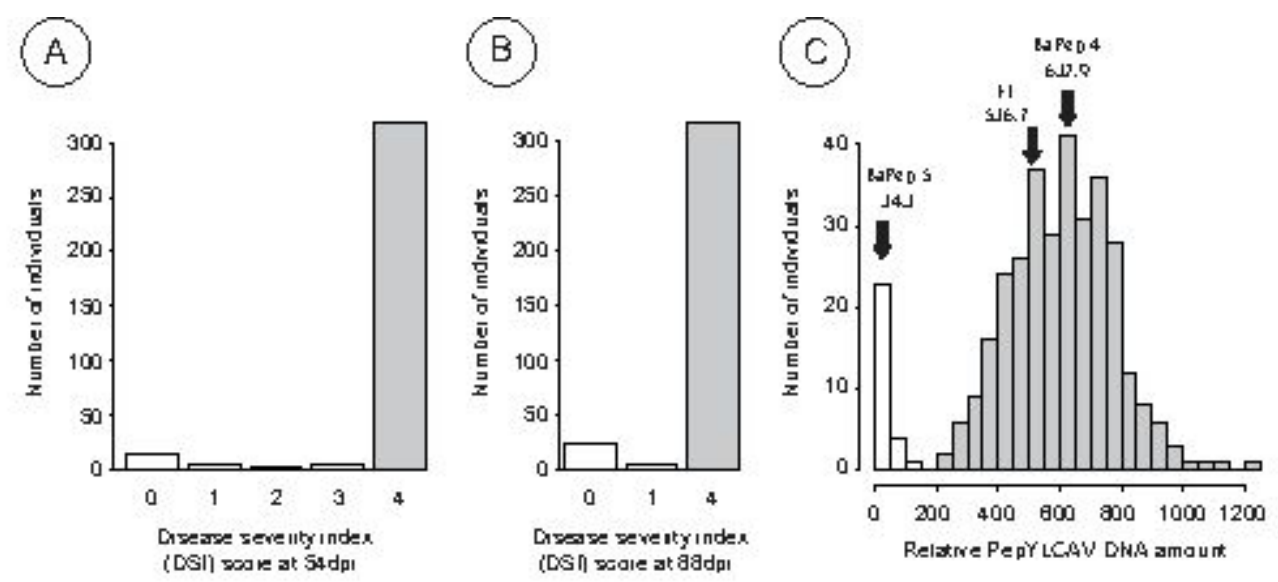

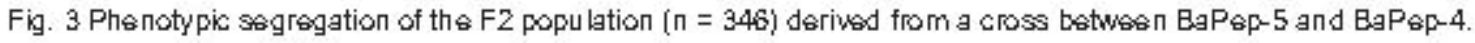
Histogram of DSI scores (A) at 54 dpi and (B) as dpi. (C) Histogram of P仓pYLCAV DNA at 54 dpi. Black amows

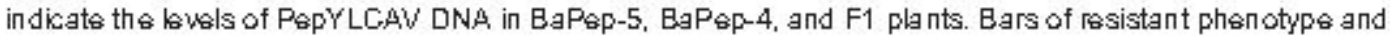
suscoptible ph@notyps ar colored in whits and gray, respectivaly.

\section{Figure 3}

Phenotypic segregation of the F2 population ( $n=346)$ derived from a cross between BaPep- 5 and BaPep4. Histogram of DSI scores (A) at 54 dpi and (B) 88 dpi. (C) Histogram of PepYLCAV DNA at 54 dpi. Black arrows indicate the levels of PepYLCAV DNA in BaPep-5, BaPep-4, and F1 plants. Bars of resistant phenotype and susceptible phenotype are colored in white and grey, respectively.

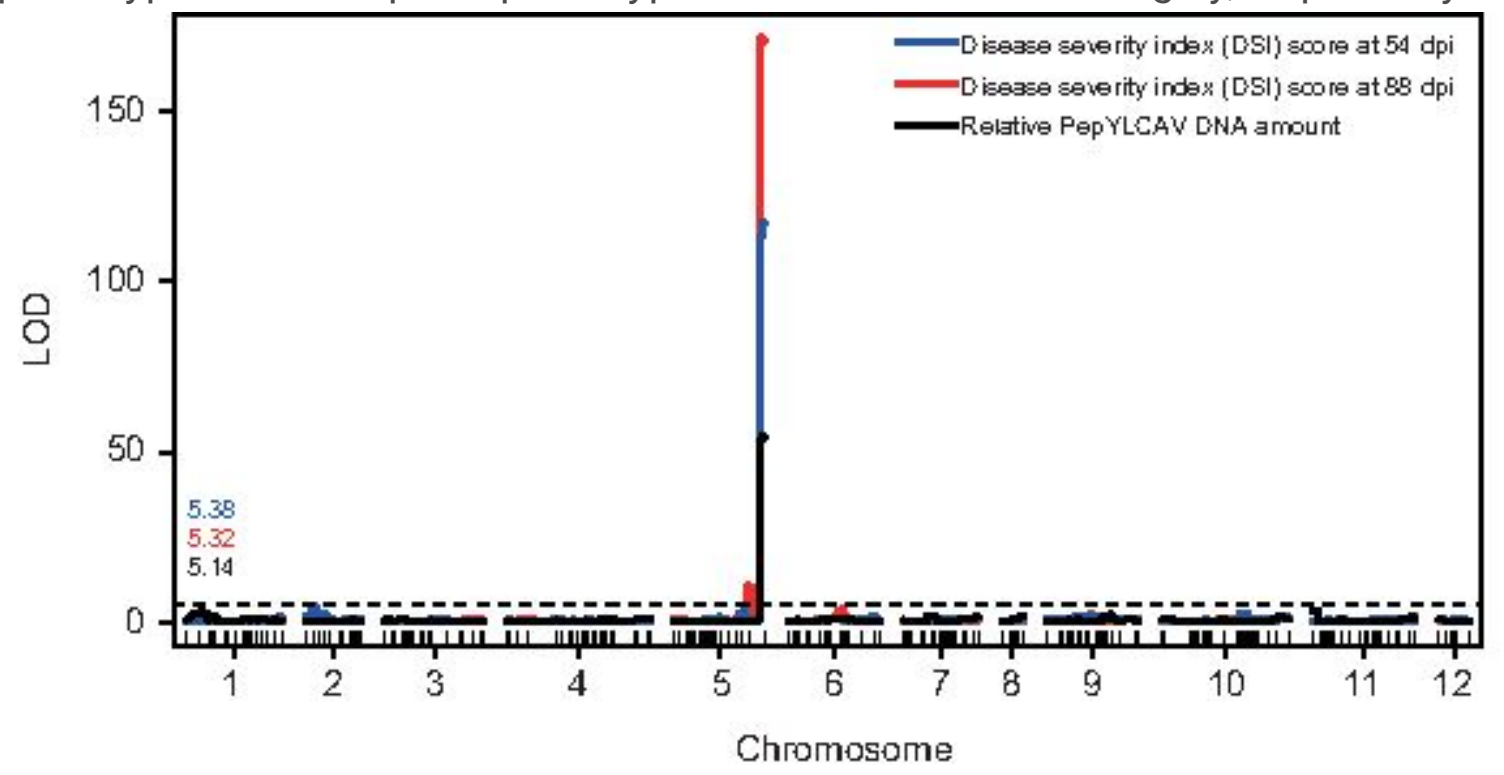

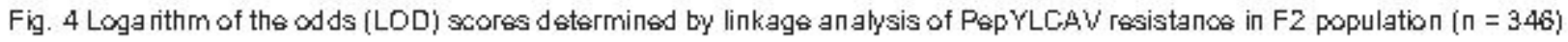

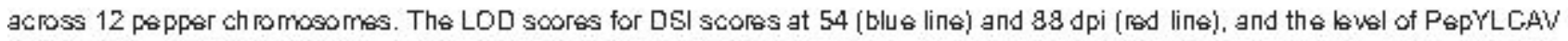
DNA at $54 \mathrm{dpi}$ (black lins) wars plott@d.

Figure 4 
Logarithm of the odds (LOD) scores determined by linkage analysis of PepYLCAV resistance in F2 population $(n=346)$ across 12 pepper chromosomes. The LOD scores for DSI scores at 54 (blue line) and $88 \mathrm{dpi}$ (red line), and the level of PepYLCAV DNA at 54 dpi (black line) were plotted.

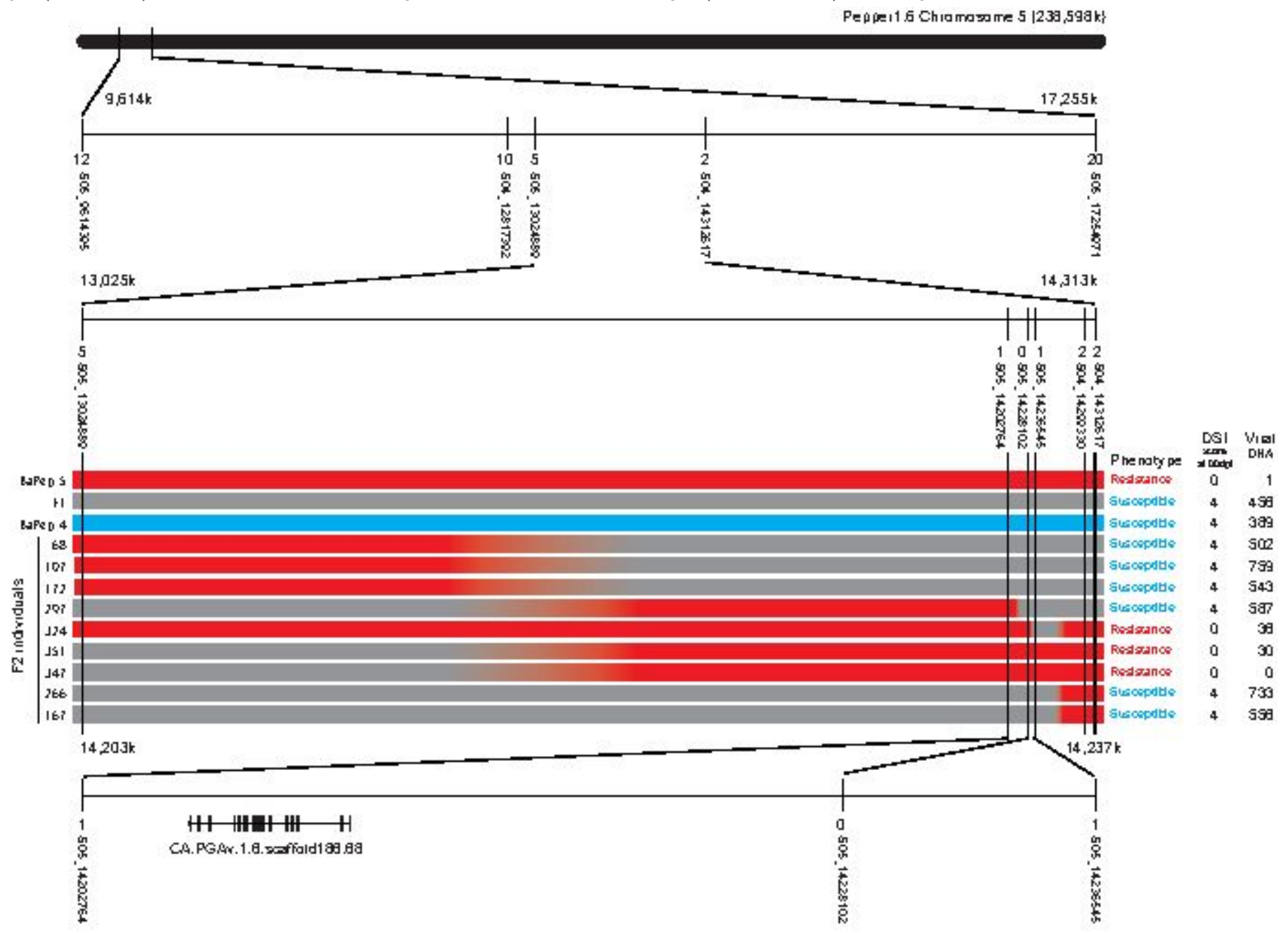

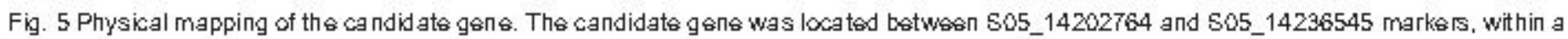

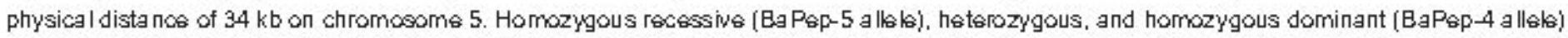

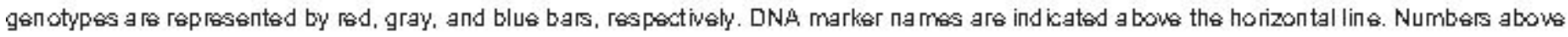
the mark@ names indicats the numbsrs of rœcombinant plants.

\section{Figure 5}

Physical mapping of the candidate gene. The candidate gene was located between S05_14202764 and S05_14236545 markers, within a physical distance of $34 \mathrm{~kb}$ on chromosome 5. Homozygous recessive (BaPep-5 allele), heterozygous, and homozygous dominant (BaPep-4 allele) genotypes are represented by red, gray, and blue bars, respectively. DNA marker names are indicated above the horizontal line. Numbers above the marker names indicate the numbers of recombinant plants. 


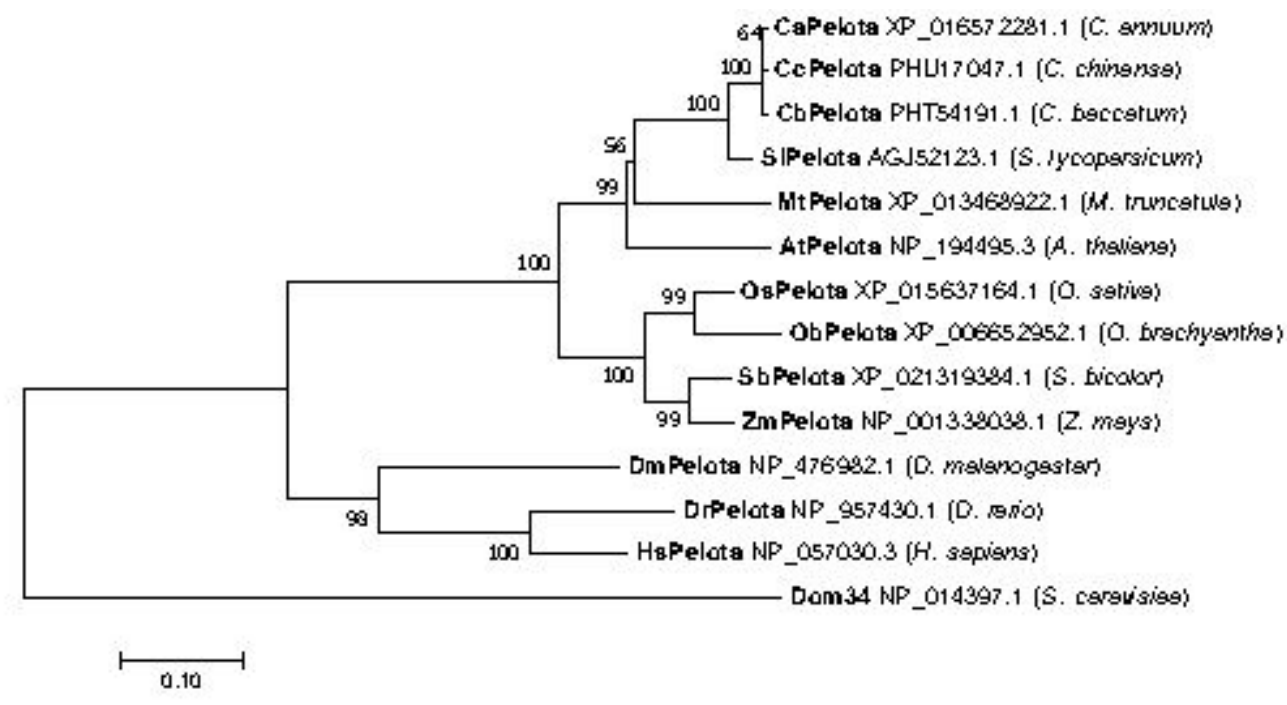

Fig. 6 Analysis of the phylogenstic slationship of CaPsbta with P仓bta of plants, an imals, and fungi. A phybgenstic tr仓s was

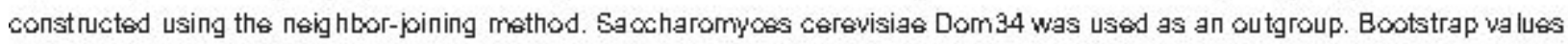

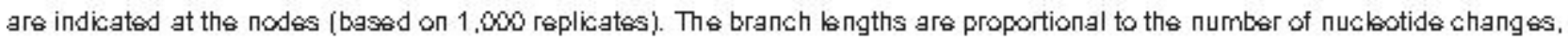
as indicat@d by tho scak bar $(0.05$ substitutions p@r sits).

\section{Figure 6}

Analysis of the phylogenetic relationship of CaPelota with Pelota of plants, animals, and fungi. A phylogenetic tree was constructed using the neighbor-joining method. Saccharomyces cerevisiae Dom34 was used as an outgroup. Bootstrap values are indicated at the nodes (based on 1,000 replicates). The branch lengths are proportional to the number of nucleotide changes, as indicated by the scale bar (0.05 substitutions per site). 


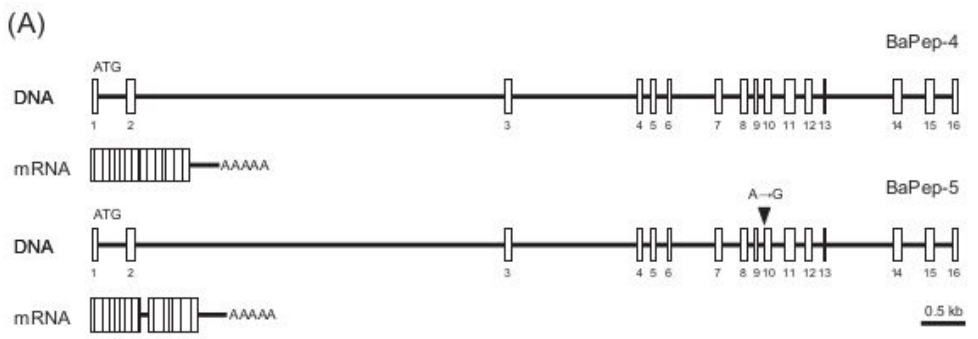

(B)

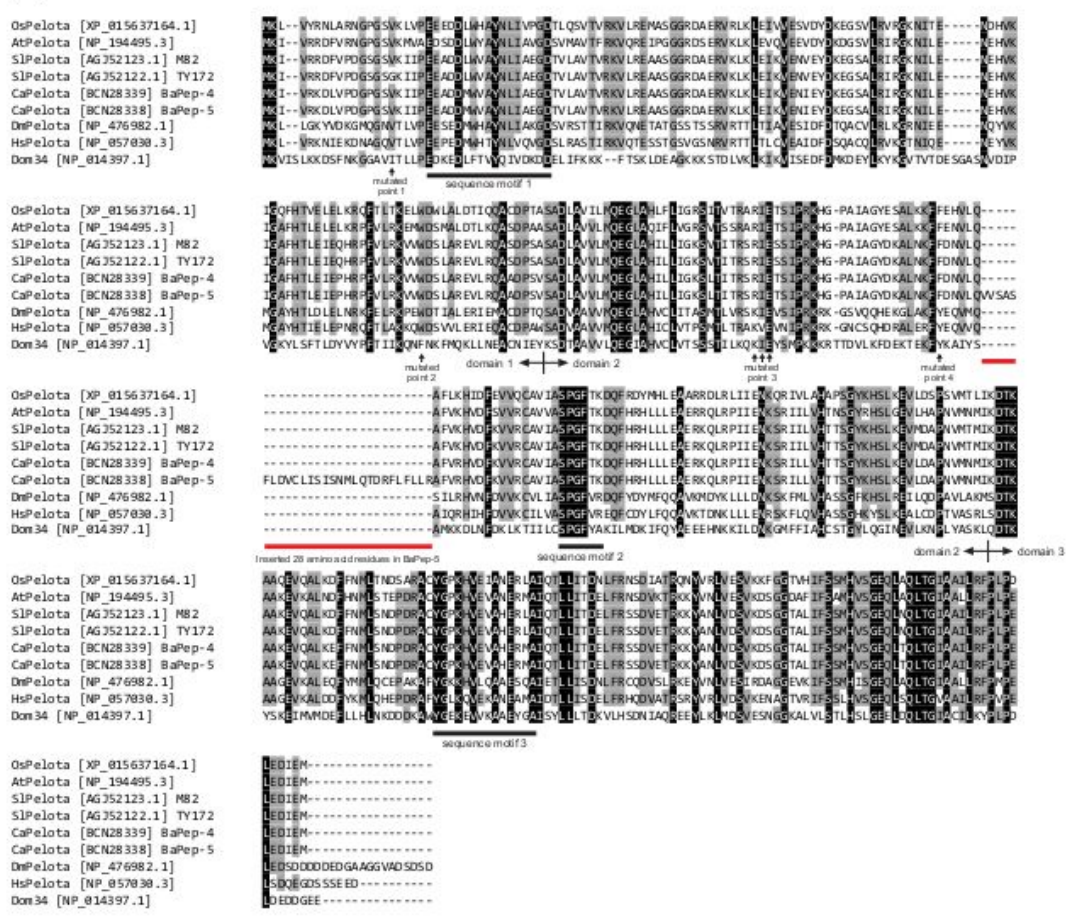

Fig. 7 Molecular genetic identification of CaPelota as the candidate gene responsible for the PepYLCAV resistant phenotype of BaPep-5. (A) Schematic diagram of CaPelota in BaPep-4 and BaPep-5. Exons (closed white boxes) were predicted from the corresponding cDNA sequences. The splice site contained an A in BaPep-4 and a G in BaPep-5, which resulted in a splicing variant involving the 9th intron of CaPelota in BaPep-5. (B) Alignment of the predicted amino acid sequences of CaPelota and its homologs in other organisms. The amino acid sequence of CaPelota of BaPep-4 (C. annuum) and BaPep-5 (C. annuum) was aligned with those of its homologs in Oryza sativa, Arabidopsis thaliana, Solanum lycopersicum (TYLCV-resistant TY172 and -susceptible M82), Drosophila melanogaster, and Homo sapiens, along with Dom 34 of S. cerevisiae using Clustal Omega. Red underbar represents the inserted 28 amino acid residues in BaPep-5; black underbars represent the sequence motifs 1,2, and 3 of domains 1,2 , and 3 , respectively; asterisks represent the predicted conserved acidic residues, which play important roles in the ribonuclease activity of Pelota (Lee et al., 2007). Mutation points 1, 2, 3, and 4 indicate mutated residues in TY172 (ty-5) (S. Iycopersicum), Im/1 (O. sativa), genomeedited $/ \mathrm{m} / 1$ mutants (Im/1-1, Im/1-2, and /m/1-3) (O. sativa), and HM47 mutant (O. sativa), respectively (Lapidot et al. 2015; Qin et al. 2018; Zhang et al. 2018).

\section{Figure 7}

Molecular genetic identification of CaPelota as the candidate gene responsible for the PepYLCAV resistant phenotype of BaPep-5. (A) Schematic diagram of CaPelota in BaPep-4 and BaPep-5. Exons (closed white boxes) were predicted from the corresponding cDNA sequences. The splice site contained an $A$ in BaPep-4 and a $G$ in BaPep-5, which resulted in a splicing variant involving the 9th intron of CaPelota in BaPep-5. (B) Alignment of the predicted amino acid sequences of CaPelota and its homologs 
in other organisms. The amino acid sequence of CaPelota of BaPep-4 (C. annuum) and BaPep-5 (C. annuum) was aligned with those of its homologs in Oryza sativa, Arabidopsis thaliana, Solanum lycopersicum (TYLCV-resistant TY172 and -susceptible M82), Drosophila melanogaster, and Homo sapiens, along with Dom34 of S. cerevisiae using Clustal Omega. Red underbar represents the inserted 28 amino acid residues in BaPep-5; black underbars represent the sequence motifs 1, 2, and 3 of domains 1 , 2 , and 3, respectively; asterisks represent the predicted conserved acidic residues, which play important roles in the ribonuclease activity of Pelota (Lee et al., 2007). Mutation points 1, 2, 3, and 4 indicate mutated residues in TY172 (ty-5) (S. Iycopersicum), Iml1 (O. sativa), genome-edited Iml1 mutants (Iml1-1, Iml1-2, and Iml1-3) (0. sativa), and HM47 mutant (0. sativa), respectively (Lapidot et al. 2015; Qin et al. 2018; Zhang et al. 2018).

(A)

$\mathrm{BaP} \odot \mathrm{p}-4$

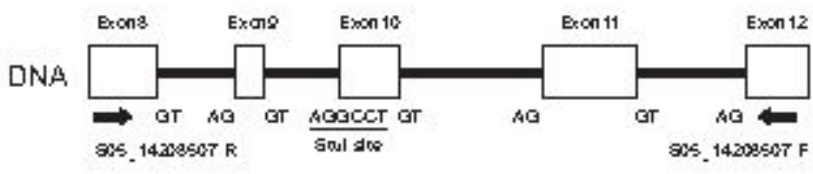

BaP@p-5

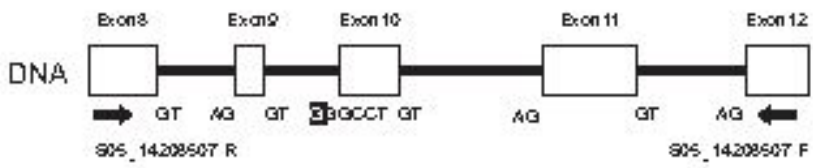

(B)

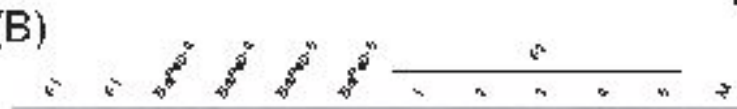

$100 \mathrm{bp}$

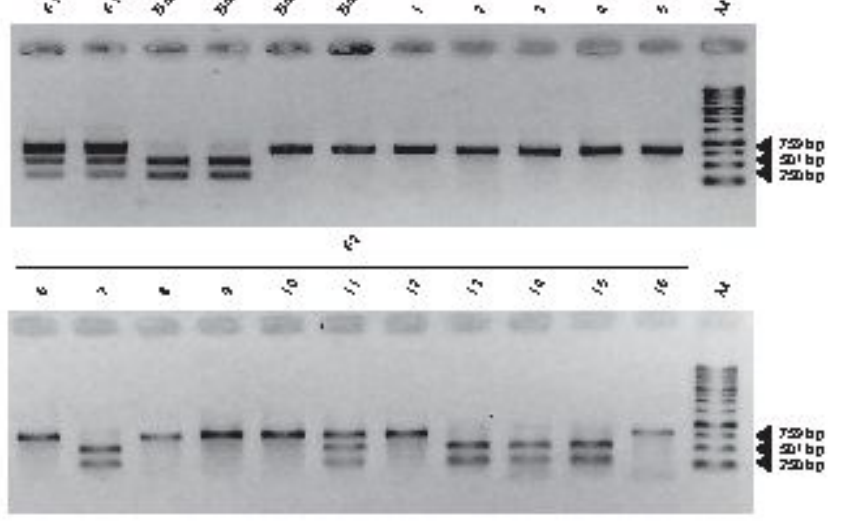

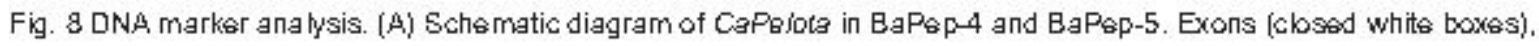

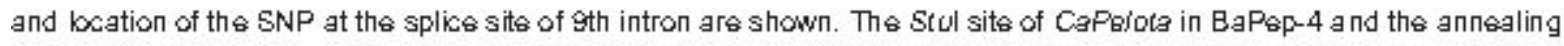
positions of S05_14208507 F and R primsrs aro also indicat@d. (B) Agarose gol showing the results of CaPbiota genotyping

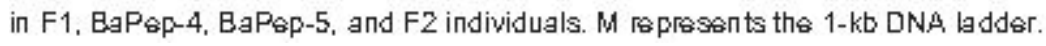

\section{Figure 8}

DNA marker analysis. (A) Schematic diagram of CaPelota in BaPep-4 and BaPep-5. Exons (closed white boxes), and location of the SNP at the splice site of 9th intron are shown. The Stul site of CaPelota in BaPep-4 and the annealing positions of S05_14208507 F and R primers are also indicated. (B) Agarose 
gel showing the results of CaPelota genotyping in $\mathrm{F} 1, \mathrm{BaPep}-4$, BaPep-5, and $\mathrm{F} 2$ individuals. $\mathrm{M}$ represents the 1-kb DNA ladder.

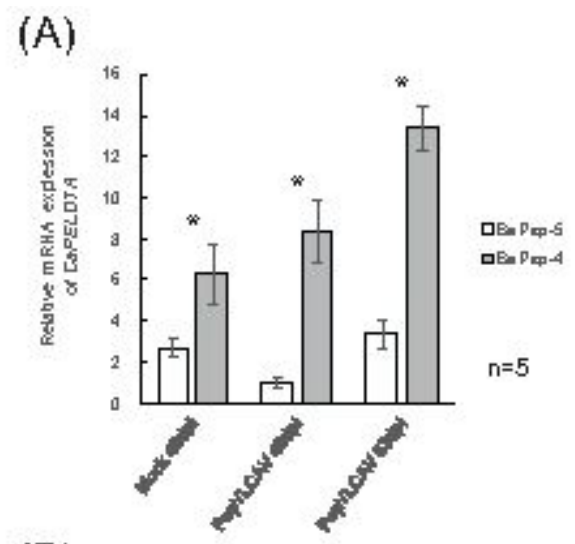

(B)
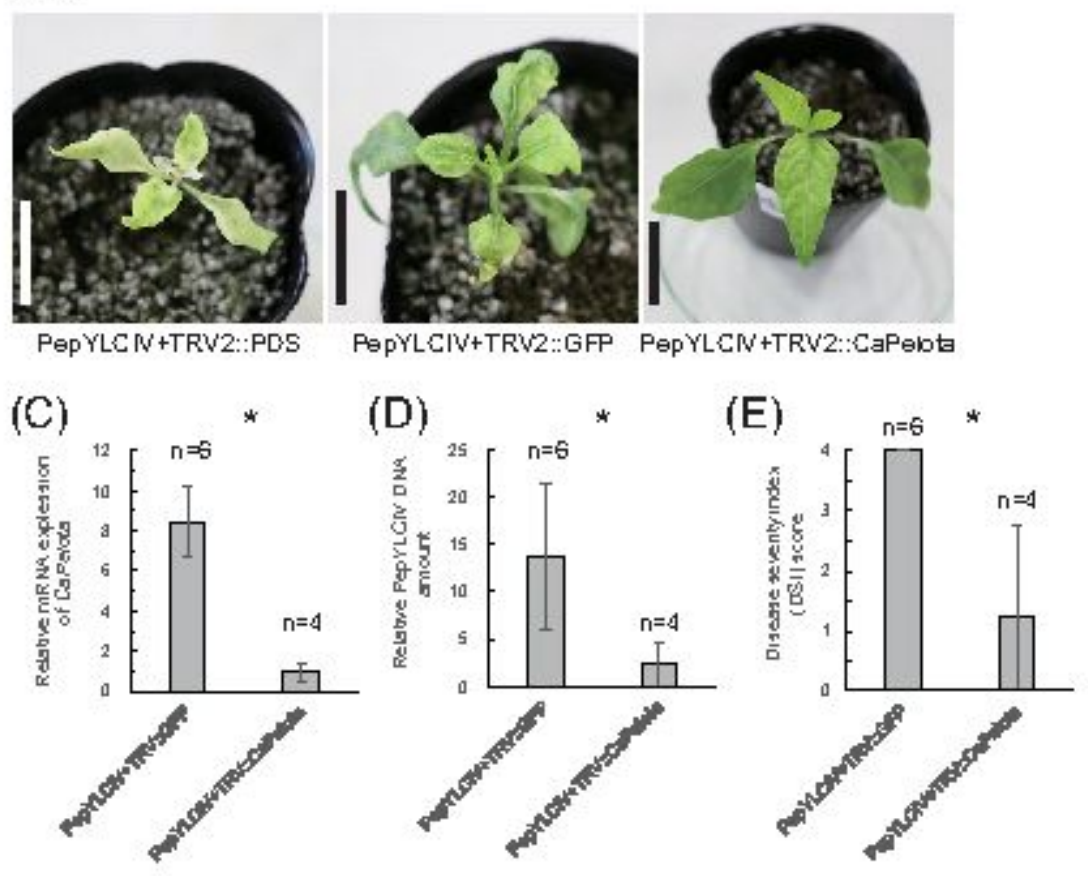

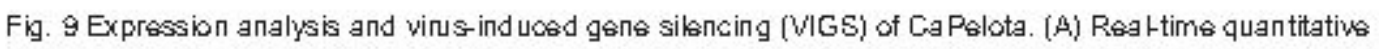

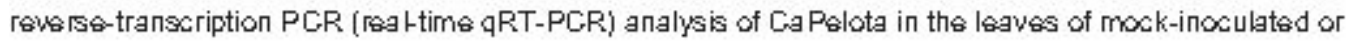

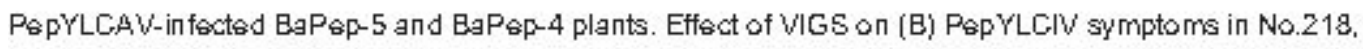

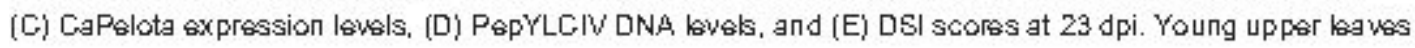

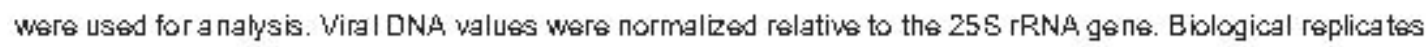

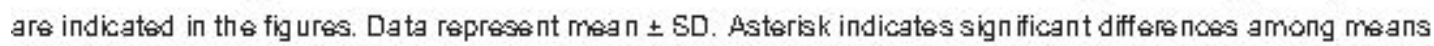
(Student's t-tøst, $p<0.05$ ).

\section{Figure 9}

Expression analysis and virus-induced gene silencing (VIGS) of CaPelota. (A) Real-time quantitative reverse-transcription PCR (real-time qRT-PCR) analysis of CaPelota in the leaves of mock-inoculated or PepYLCAV-infected BaPep-5 and BaPep-4 plants. Effect of VIGS on (B) PepYLCIV symptoms in No.218, (C) CaPelota expression levels, (D) PepYLCIV DNA levels, and (E) DSI scores at 23 dpi. Young upper leaves were used for analysis. Viral DNA values were normalized relative to the 25S rRNA gene. Biological 
replicates are indicated in the figures. Data represent mean \pm SD. Asterisk indicates significant differences among means (Student's t-test, $p<0.05$ ).

\section{Supplementary Files}

This is a list of supplementary files associated with this preprint. Click to download.

- SupplementaryFig.S1.pdf

- SupplementaryFig.S2.docx

- SupplementaryFig.S3.eps

- Tables1.pdf

- Tables2.pdf

- TableS3.pdf 